\title{
Sandwich and half-sandwich metal complexes derived from cross-conjugated 3-methylene-penta-1,4-diynes
}

Article

Accepted Version

Vincent, K. B., Gluyas, J. B. G., Zeng, Q., Yufit, D. S., Howard, J. A. K., Hartl, F. and Low, P. J. (2017) Sandwich and halfsandwich metal complexes derived from cross-conjugated 3methylene-penta-1,4-diynes. Dalton Transactions, 46 (17). pp. 5522-5531. ISSN 1364-5447 doi:

https://doi.org/10.1039/c6dt04470k Available at https://centaur.reading.ac.uk/68548/

It is advisable to refer to the publisher's version if you intend to cite from the work. See Guidance on citing.

To link to this article DOI: http://dx.doi.org/10.1039/c6dt04470k

Publisher: Royal Society of Chemistry

All outputs in CentAUR are protected by Intellectual Property Rights law, including copyright law. Copyright and IPR is retained by the creators or other copyright holders. Terms and conditions for use of this material are defined in the End User Agreement. 


\section{CentAUR}

Central Archive at the University of Reading

Reading's research outputs online 


\section{Sandwich and half-sandwich metal complexes derived from cross-conjugated 3-methylene-penta-1,4-diynes}

Kevin B. Vincent, ${ }^{\mathrm{a}}$ Josef B. G. Gluyas, ${ }^{\mathrm{b}}$ Qiang Zeng, ${ }^{\text {,dd }}$ Dmitry S. Yufit, ${ }^{\mathrm{a}}$ Judith A. K. Howard, ${ }^{\mathrm{a}}$ Frantisek Hartl, ${ }^{* *}$ and Paul J. Low. ${ }^{\mathrm{a}, \mathrm{b} *}$

a Department of Chemistry, Durham University, South Rd, Durham, DH1 3LE, UK

b School of Chemistry and Biochemistry, University of Western Australia, 35 Stirling Highway, Crawley 6009, WA, Australia.

${ }^{c}$ Department of Chemistry, University of Reading, Whiteknights, Reading, RG6 6AH, $U K$

d School of Chemistry and Chemical Engineering, South China University of Technology, Guangzhou 510640, PR China

* Corresponding authors:

PJL:paul.low@uwa.edu.au (t)+61864883045

FH:f.hartl@reading.ac.uk (t) +44 (0) 1183787695

Keywords: ethynyl; ferrocene; ruthenium; cross-conjugated 


\section{Abstract}

The

cross-conjugated

ethynyl-vinylidene

$\left[\mathrm{Ph}_{2} \mathrm{C}=\mathrm{C}(\mathrm{C} \equiv \mathrm{CH})\left\{\mathrm{C}(\mathrm{H})=\mathrm{CRu}\left(\mathrm{PPh}_{3}\right)_{2} \mathrm{Cp}\right\}\right] \mathrm{PF}_{6}$

$\left([\mathbf{4 a}] \mathrm{PF}_{6}\right)$,

and

$\left[\mathrm{FcC}(\mathrm{H})=\mathrm{C}(\mathrm{C} \equiv \mathrm{CH})\left\{\mathrm{C}(\mathrm{H})=\mathrm{CRu}\left(\mathrm{PPh}_{3}\right)_{2} \mathrm{Cp}\right\}\right] \mathrm{PF}_{6} \quad\left([\mathbf{4 b}] \mathrm{PF}_{6}\right)$, and ethynyl-alkynyl $\mathrm{Ph}_{2} \mathrm{C}=\mathrm{C}(\mathrm{C} \equiv \mathrm{CH})\left\{\mathrm{C} \equiv \mathrm{CRu}\left(\mathrm{PPh}_{3}\right)_{2} \mathrm{Cp}\right\} \quad$ (5a), and $\mathrm{FcC}(\mathrm{H})=\mathrm{C}(\mathrm{C} \equiv \mathrm{CH})\left\{\mathrm{C} \equiv \mathrm{CRu}\left(\mathrm{PPh}_{3}\right)_{2} \mathrm{Cp}\right\}$ (5b) compounds ( $\mathrm{Cp}=\eta^{5}$-cyclopentadienyl) have been prepared from reactions of the known 3-methylene-penta-1,4-diynes $\mathrm{Ph}_{2} \mathrm{C}=\mathrm{C}(\mathrm{C} \equiv \mathrm{CH})_{2} \quad$ (3a) and $\left[\mathrm{FcCH}=\mathrm{C}(\mathrm{C} \equiv \mathrm{CH})_{2}\right](\mathbf{3 b})$ with $\left[\mathrm{RuCl}\left(\mathrm{PPh}_{3}\right)_{2} \mathrm{Cp}\right]$. The compounds derived from $\mathbf{3 b}$ incorporating the more electron-rich alkene proved to be unstable during workup, and attempts to prepare bis(ruthenium) complexes from $\mathbf{3 a}$ and $\mathbf{3 b}$ or from transmetallation reactions of the bis(alkynylgold) complex $\mathrm{FcCH}=\mathrm{C}(\mathrm{C} \equiv \mathrm{CAuPPh})_{2}(7)$ with $\mathrm{RuCl}\left(\mathrm{PPh}_{3}\right)_{2} \mathrm{Cp}$ were unsuccessful. The related bis- and tris(ferrocenyl) derivatives $\mathrm{Ph}_{2} \mathrm{C}=\mathrm{C}(\mathrm{C} \equiv \mathrm{CFc})_{2}(\mathbf{6 a})$ and $\mathrm{FcCH}=\mathrm{C}(\mathrm{C} \equiv \mathrm{CFc})_{2}$ (6b) were more readily obtained from $\mathrm{Pd}(\mathrm{II}) / \mathrm{Cu}(\mathrm{I})$ catalysed cross-coupling reactions of $\mathrm{FcC} \equiv \mathrm{CH}$ with the 1,1-dibromo vinyl complexes $\mathrm{PhC}=\mathrm{CBr}_{2}$ (1a) and $\mathrm{FcC}(\mathrm{H})=\mathrm{CBr}_{2}(\mathbf{1 b})$. Cyclic voltammetry of $\mathbf{6 a}$ and $\mathbf{6 b}$ using $n-\mathrm{Bu}_{4} \mathrm{~N}\left[\mathrm{PF}_{6}\right]$ as the supporting electrolyte shows broad, overlapping waves arising from the sequential oxidation of the ferrocenyl moieties in electronically and chemically similar environments. Electrostatic effects between the ferrocenyl moieties are enhanced in solutions of the weakly ion-pairing electrolyte $n-\mathrm{Bu}_{4} \mathrm{~N}\left[\mathrm{~B}\left\{\mathrm{C}_{6} \mathrm{H}_{3}\left(\mathrm{CF}_{3}\right)_{2}\right.\right.$ $\left.3,5\}_{4}\right]$, leading to better resolution of the individual electrochemical processes. The comparative IR spectroelectrochemical response of $\mathbf{6 a}$ and $\mathbf{6 b}$ suggest the vinyl ferrocene moiety in $\mathbf{6 b}$ undergoes oxidation before the ethynyl ferrocene fragments. There is no evidence of electronic coupling between the metallocene moieties and $[\mathbf{6 a}]^{+},[\mathbf{6} \mathbf{b}]^{\mathrm{n}+}(\mathrm{n}=1,2)$ are best described as Class I mixed-valence compounds.

\section{Introduction}

Ferrocene has long been used as an electrophore in the design and study of mixedvalence (MV) compounds.\{Nishihara:2002ck\} In the 1970s Cowan demonstrated that biferrocenyl was able to undergo one-electron oxidation to give a Class II MV compound with a characteristic inter-valence charge transfer (IVCT) band centred at ca. $1900 \mathrm{~nm}$ (5260 cm-1).\{Cowan:1970cq, Cowan:1972cp, Cowan:1971kc, 
Cowan:1972gu, Talham:1984bi\} Studies of the redox properties of related 1,2bis(ferrocenyl)ethenes also revealed thermodynamically stable MV compounds to be formed on one-electron oxidation.\{DelgadoPena:1983js\} Although spectroscopic studies of the $Z$-isomers were complicated by isomerisation, $\{$ Chen:2000gz $\}$ available data support the description of these compounds as less strongly coupled Class II systems. Studies of MV complexes derived from 1,4-bis(ferrocenyl)buta-1,3-dienes such as $\mathrm{FcC}(\mathrm{H})=\mathrm{C}(\mathrm{H}) \mathrm{C}(\mathrm{H})=\mathrm{C}(\mathrm{H}) \mathrm{Fc}$ are also complicated by a range of issues relating to facile interconversion between the cis and trans isomers. \{Ribou:1996cw\} Related structures in which the diene fragment is (conceptually) constrained into a heterocyclic structure have proven to be more amenable to study, and a combination of spectroscopic and computational studies have indicated that these heterocyclic bridged MV compounds can be considered as Class II MV complexes, with the diene-like backbone contributing significantly to the optical charge transfer transition.\{Lehrich:2014du, Miesel:2015je, Miesel:2013ht\}

The thermodynamic stability of MV derivatives of the structurally simple, linear $\alpha, \omega$-bis(ferrocenyl) oligo(ynes) $\mathrm{Fc}(\mathrm{C} \equiv \mathrm{C})_{\mathrm{X}} \mathrm{Fc}$ decreases as the oligoyne chain length increases, such that the ferrocene redox processes in 1,6-bis(ferrocenyl)hexa1,3,5-triyne are heavily overlapped.\{Levanda:2002du, Shah:2013in, Xu:2006je\} Although the 1,8-bis(ferrocenyl)octa-1,3,5,7-tetrayne has been prepared,\{Yuan:1993dx\} we are unaware of any studies of mixed-valence analogues of this compound; in the case of the 1,12-bis(ferrocenyl)dodeca1,3,5,7,9,11-hexayne the ferrocene moieties give rise to two genuinely independent oxidation processes in a $0.1 \mathrm{M} n$ - $\mathrm{Bu}_{4} \mathrm{NPF}_{6}\left(1: 1 \mathrm{CH}_{2} \mathrm{Cl}_{2} / \mathrm{NCMe}\right)$ electrolyte. $\{$ Adams:2002dm\} Although spectroscopic data from these longer MV complexes are limited, those that are available, indicate that the interactions between the ferrocenyl moieties decrease with increasing the bridge length.

In contrast, oligoenediyl- and oligoynediyl-bridged complexes of electron-rich ruthenium phosphine moieties generally give rise to much more extensively delocalised radical cations on oxidation, as in $\left[\left\{\mathrm{Ru}\left(\mathrm{PPh}_{3}\right)_{2}(\mathrm{CO}) \mathrm{Cl}_{2}(\mu-\right.\right.$ 
$\left.\mathrm{CH}=\mathrm{CHCH}=\mathrm{CH})], \quad\left[\left\{\mathrm{Ru}_{(\mathrm{PEt}}\right)_{3}(\mathrm{CO}) \mathrm{Cl}\right\}_{2}(\mu-\mathrm{CH}=\mathrm{CHCH}=\mathrm{CH})\right]$, and $\left[\left\{\mathrm{Ru}\left(\mathrm{PPh}_{3}\right)_{2}(\mathrm{CO})\right.\right.$ $\left.\left.\mathrm{Cl}\left(\mathrm{NC}_{5} \mathrm{H}_{4} \mathrm{COOEt}-4\right)\right\}_{2}(\mu-\mathrm{CH}=\mathrm{CHCH}=\mathrm{CH})\right]\{$ Maurer:2005es $\}$ and the various spectroscopically identified rotamers of $\left\{\mathrm{Cp}^{\prime}\left(\mathrm{L}_{2}\right) \mathrm{Ru}\right\}_{2}(\mu-\mathrm{C} \equiv \mathrm{CC} \equiv \mathrm{C})\left(\mathrm{Ru}\left(\mathrm{L}_{2}\right) \mathrm{Cp}^{\prime}=\right.$ $\mathrm{Ru}\left(\mathrm{PPh}_{3}\right)_{2} \mathrm{Cp},\{$ Parthey:2013gu, Bruce:2000jc, Gluyas:2016cc $\}$ $\mathrm{Ru}\left(\mathrm{PMe}_{3}\right)\left(\mathrm{PPh}_{3}\right) \mathrm{Cp},\{$ Bruce:2000jc $\} \mathrm{Ru}($ dppe)Cp,\{Gluyas:2016cc $\} \mathrm{Ru}(\mathrm{dpp}) \mathrm{Cp}^{*}$ \{Gluyas:2016cc\}). However, the substantial contributions from the unsaturated bridging ligand to the semi-occupied molecular orbitals (SOMOs) suggests that such systems are better described in terms of bridge-localised radical cations than true mixed-valence complexes.\{Schauer:2012jb\} \{Low:2013fy, Winter:2014kg\}

In addition to linear systems, a variety of compounds featuring more than two ferrocene or ruthenium moieties linked through a common but branched bridging ligand have been explored. Interest in such multiple electrophore complexes include the fundamental mechanisms and methods of analysis of charge transfer through '2-dimensional' frameworks, $\{$ Heckmann:2012gw $\}$ and assessment of the optoelectronic properties of branched molecules.\{Wilson:2003tm, Zucchero:2009gp, Wilson:2004tm \} Exemplary molecular systems include 1,3,5tris(ferrocenylethynyl)benzene,\{Fink:1997gt $\}$ and Astruc's 1,2,3,4,5,6hexakis(ferrocenylethynyl)benzenes,\{Diallo:2011bw, Diallo:2009cf $\}$ which exhibit electrostatic interactions between the ferrocenyl moieties upon oxidation, if not true electronic delocalisation. The use of electrolytes with weakly ionpairing anions such as $n-\mathrm{Bu} 4 \mathrm{~N}\left[\mathrm{~B}\left\{\mathrm{C}_{6} \mathrm{H}_{3}\left(\mathrm{CF}_{3}\right)_{2}-3,5\right\}_{4}\right]$ enhances through-space (or Coulombic) interactions between nearby electrophores, leading to the resolution of individual electrochemical events.\{Geiger:2010gb\} For further example, although there is no significant electronic coupling between the ferrocene moieties in tetraferrocenyl(nickel dithiolene), in $n-\mathrm{Bu} 4 \mathrm{~N}\left[\mathrm{~B}\left\{\mathrm{C}_{6} \mathrm{H}_{3}\left(\mathrm{CF}_{3}\right)_{2}-3,5\right\}_{4}\right]$ four distinct oxidation events (and two dithiolene based reductions) are observed by differential pulse voltammetry.\{Barriere:2002iv\}

Cross-conjugated $\pi$-systems are potential scaffolds upon which to further develop such interests, \{Gholami:2006ds, Anthony:1995kb, Phelan:1968kf\} and attention is now being directed towards the synthesis and properties of complexes featuring cross-conjugated bridging ligands such as ene-ynes.\{Natoli:2016hj, Natoli:2015hf, 
Forrest:2015ch\} We have recently described a range of mono(ferrocenyl) derivatives of 3-methylene-penta-1,4-diyne, which were obtained from crosscoupling reactions of alkynes with 1,1-dibromo-2-ferrocenyl ethane, $\{$ Vincent:2013fd $\}$ and also the step-wise assembly of 1,1,2,2tetrakis(ferrocenylethynyl)ethane.\{Vincent:2016eu\} The latter revealed wellresolved sequence of four ferrocene-based oxidations in $n-\mathrm{Bu}_{4} \mathrm{~N}\left[\mathrm{~B}\left\{\mathrm{C}_{6} \mathrm{H}_{3}\left(\mathrm{CF}_{3}\right)_{2}-\right.\right.$ $\left.3,5\}_{4}\right]$, although there was no clear spectroscopic evidence for any significant coupling between the ferrocene / ferrocenium moieties. Now attention is turned to related compounds featuring both ruthenium half-sandwich and ferrocene electrophores. In this contribution further synthetic explorations of metal complexes of 3-methylene-penta-1,4-diyne are described, together with the electrochemical characteristics of the tris(ferrocenyl) complex $\mathrm{FcC}(\mathrm{H})=\mathrm{C}(\mathrm{C} \equiv \mathrm{CFc}) 2$.

\section{Results \& Discussion}

The half-sandwich bis(phosphine) ruthenium complexes, exemplified by $\left[\mathrm{RuCl}\left(\mathrm{PPh}_{3}\right)_{2} \mathrm{Cp}\right]$, undergo facile reaction with terminal alkynes, $\mathrm{HC} \equiv \mathrm{CR}$, to give vinylidene complexes (e.g., $\left.\left[\mathrm{Ru}\{\mathrm{C}=\mathrm{C}(\mathrm{H}) \mathrm{R}\}\left(\mathrm{PPh}_{3}\right)_{2} \mathrm{Cp}\right]^{+}\right)$which in turn are readily deprotonated to the acetylide complexes (e.g. $\left.\left[\mathrm{Ru}(\mathrm{C} \equiv \mathrm{CR})\left(\mathrm{PPh}_{3}\right)_{2} \mathrm{Cp}\right]\right) .\{$ Bruce:1978kp $\}$ Complexes of this type continue to serve as workhorses for the exploration of vinylidene and acetylide ligand chemistry since the inception of the field in the 1980s.\{Lynam:2010ij, Bruce:1983uo, Long:2003kr\} However, attempts to access the chemistry of ruthenium complexes featuring cross-conjugated ligand systems by reaction of $\left[\mathrm{RuCl}(\mathrm{dppe}) \mathrm{Cp}^{*}\right]$ with penta-3-one-1,4-diyne $(\mathrm{HC} \equiv \mathrm{CC}(=0) \mathrm{C} \equiv \mathrm{CH})$ were unsuccessful; instead, reaction of $\left[\mathrm{Ru}(\mathrm{C} \equiv \mathrm{CH})(\mathrm{dppe}) \mathrm{Cp}^{*}\right]$ with oxalyl chloride gave the bimetallic complex $\left[\left\{\mathrm{Ru}(\mathrm{dppe}) \mathrm{Cp}^{*}\right\}_{2}\{\mu-\mathrm{C} \equiv \mathrm{C}(\mathrm{CO}) \mathrm{C} \equiv \mathrm{C}\}\right]$ in good yield, providing a platform for further synthetic transformations of the cross-conjugated bridging ligand.\{Bruce:2013je\} However, a more direct route to such complexes is still to be developed.

Benzophenone, $\mathrm{PhC}(=0) \mathrm{Ph}$, is conveniently transformed to 1,1-dibromo-2,2diphenyl ethene 1a (79\%) on reaction with $\mathrm{CBr}_{4}$ and PPh3.\{Donovan:2004dj\} The dibromoethene $\mathbf{1 a}$ is in turn smoothly cross-coupled ([Pd(PPh $\left.)_{4}\right]$ / CuI catalyst) 
with trimethylsilylacetylene, $\mathrm{Me}_{3} \mathrm{SiC} \equiv \mathrm{CH}$, to give the bis(alkyne) $\mathrm{Ph}_{2} \mathrm{C}=\mathrm{C}\left(\mathrm{C} \equiv \mathrm{CSiMe}_{3}\right)_{2} \quad$ (2a, 84\%), and desilylated $\left(\mathrm{K}_{2} \mathrm{CO}_{3} / \mathrm{MeOH}\right)$ to give $\mathrm{Ph}_{2} \mathrm{C}=\mathrm{C}(\mathrm{C} \equiv \mathrm{CH})_{2}(3 \mathbf{a}, 95 \%)($ Scheme 1). $\{$ Donovan:2004dj $\}$ Reactions of 2a and 3a with two equivalents of $\left[\mathrm{RuCl}\left(\mathrm{PPh}_{3}\right)_{2} \mathrm{Cp}\right]$ were explored in a range of solvents (THF, $\mathrm{MeOH}, \mathrm{CH}_{2} \mathrm{Cl}_{2}$ ) and conditions (2a: KF, $n$-Bu $4 \mathrm{NF}$; 3a: $\mathrm{NH}_{4} \mathrm{PF}_{6}, n-\mathrm{Bu}_{4} \mathrm{NPF}_{6}$, $\mathrm{KPF}_{6}$; room temperature - reflux; 1 - $24 \mathrm{~h}$ ). In all cases, in situ NMR monitoring revealed the formation of the monovinylidene [4a]PF6 and unreacted $\left[\mathrm{RuCl}\left(\mathrm{PPh}_{3}\right)_{2} \mathrm{Cp}\right]$. The synthesis of [4a]PF 6 was subsequently optimised from the 0.9:1 reaction of $\left[\mathrm{RuCl}\left(\mathrm{PPh}_{3}\right)_{2} \mathrm{Cp}\right]$ with $3 \mathrm{a}\left(\mathrm{CH}_{2} \mathrm{Cl}_{2} / \mathrm{KPF}_{6} /\right.$ reflux / $\left.20 \mathrm{hrs}\right)$ and isolated in 79\% yield by precipitation with diethyl ether (Scheme 1). The ${ }^{31 P}$ NMR spectrum of [4a]PF 6 is characterised by a singlet at $\delta 41.62 \mathrm{ppm}$, whist in the ${ }^{1} \mathrm{H}$ NMR spectrum the vinylidene ligand is evinced by a triplet at $\delta 4.92 \mathrm{ppm}\left(U_{\mathrm{HP}}=2.5\right.$ $\mathrm{Hz}$ ) and the free ethynyl moiety by a singlet at $\delta 3.09 \mathrm{ppm}$. The $\mathrm{Cp}$ ligand gave a low field resonance typical of the $\left\{\mathrm{Ru}\left(\mathrm{PPh}_{3}\right)_{2} \mathrm{Cp}\right\}^{+}$fragment at $\delta 5.23 \mathrm{ppm}$. The IR spectrum contained the anticipated vinylidene $v(C=C)\left(1629 \mathrm{~cm}^{-1}\right)$, alkyne $v(C \equiv C)$ $\left(2108 \mathrm{~cm}^{-1}\right)$ and ethene $\left(1483 \mathrm{~cm}^{-1}\right)$ bands. Other spectroscopic and analytical data were in accord with the proposed structure, which was confirmed by single crystal X-ray analysis (vide infra).

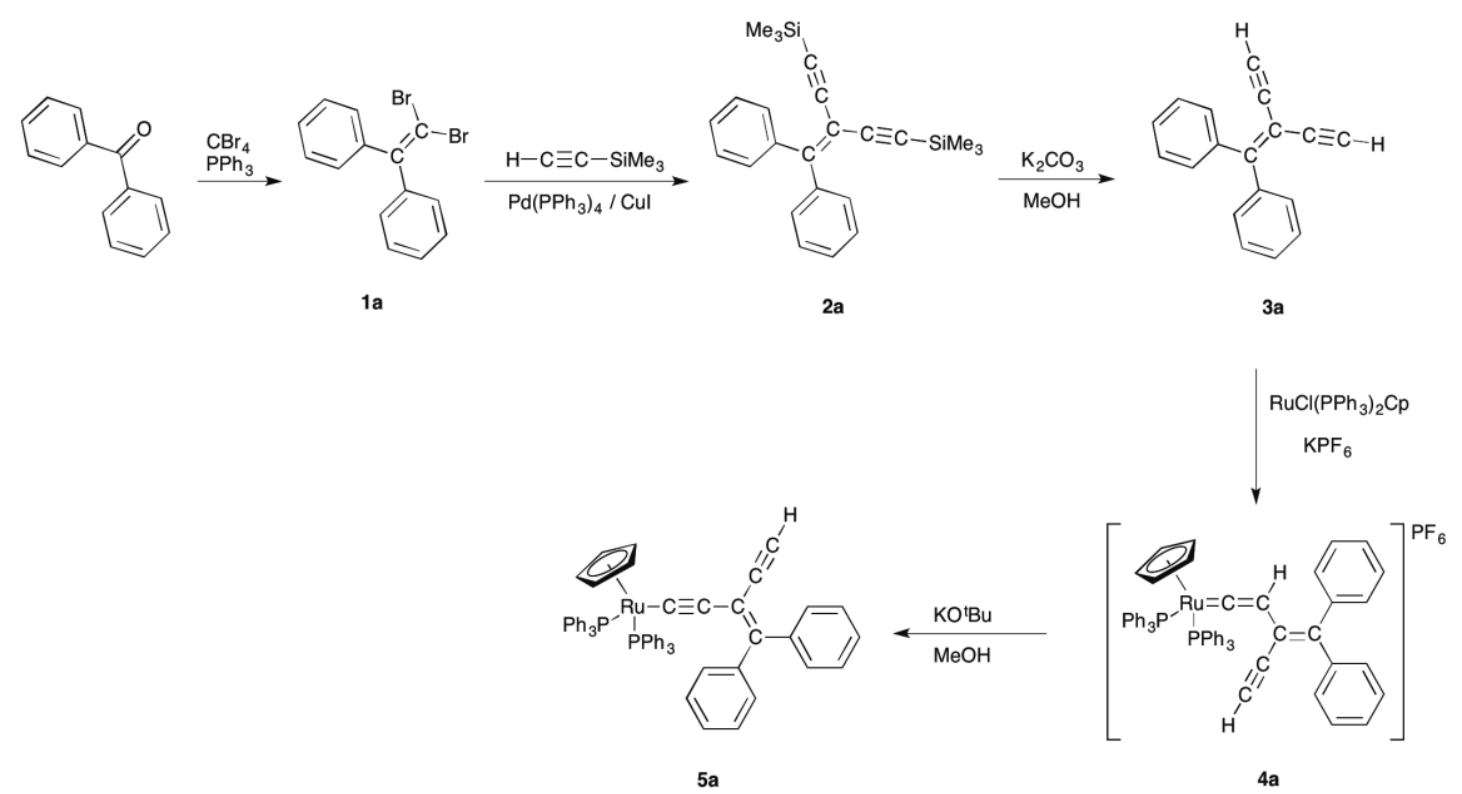

Scheme 1 The synthesis of $\mathbf{1 a} \mathbf{- 5 a}$. 
Treatment of a suspension of [4a] $\mathrm{PF}_{6}$ in methanol with $\mathrm{KO}^{\text {tBu }}$ gave the ethynylalkynyl complex 5a as a bright yellow precipitate (62\%) (Scheme 1). In the ${ }^{31} \mathrm{P}$ NMR spectrum, the half-sandwich fragment gave rise to a singlet at $\delta 50.35 \mathrm{ppm}$, whilst the $\mathrm{Cp}$ moiety was detected as a singlet in the ${ }^{1} \mathrm{H}$ NMR spectrum at $\delta 4.22$ ppm, together with a singlet from the free ethynyl proton at $\delta 2.77 \mathrm{ppm}$. The IR spectrum contained $v(\mathrm{C} \equiv \mathrm{C})$ bands from both free $\left(2105 \mathrm{~cm}^{-1}\right)$ and coordinated $\left(2044 \mathrm{~cm}^{-1}\right)$ alkyne moieties in addition to the ethene $v(C=C)$ band at $1482 \mathrm{~cm}^{-1}$. Again, other spectroscopic and analytical data, and a single crystal X-ray structure determination, confirmed the structure. Further attempts to metallate the free ethynyl fragment in $\mathbf{5 a}$ were also unsuccessful.

Table 2. Selected bond lengths $(\AA)$ and angles $\left({ }^{\circ}\right)$ from the crystallographically determined structures of $[\mathbf{4 a}] \mathrm{PF}_{6}$, and $\mathbf{5 a}$.

\begin{tabular}{lllllc}
\hline & [4a]PF6 & \multicolumn{1}{c}{ 5a } & & [4a]PF 6 & 5a \\
\hline Ru1-C1 & $1.842(3)$ & $2.0017(15)$ & Ru1-C1-C2 & $172.2(2)$ & $173.20(13)$ \\
C1-C2 & $1.328(4)$ & $1.2202(2)$ & C1-C2-C3 & $125.6(2)$ & $170.57(17)$ \\
C2-C3 & $1.475(3)$ & $1.430(2)$ & C2-C3-C4 & $115.1(2)$ & $114.74(14)$ \\
Ru1-P1 & $2.3290(6)$ & $2.2831(4)$ & C2-C3-C6 & $132.2(2)$ & $125.27(15)$ \\
Ru1-P2 & $2.3705(7)$ & $2.2923(4)$ & P1-Ru1- & $87.49(8)$ & $89.09(4)$ \\
& & & C1 & & \\
C3-C4 & $1.435(4)$ & $1.444(2)$ & P2-Ru1- & $98.39(8)$ & $90.83(4)$ \\
& & & C1 & & \\
C4-C5 & $1.190(4)$ & $1.189(2)$ & & & \\
C3-C6 & $1.371(4)$ & $1.375(2)$ & & & \\
\hline
\end{tabular}

The molecular structures of [4a] $\mathrm{PF}_{6}$ and $\mathbf{5 a}$ are plotted in Figures 1 and 2, and illustrate the rather congested environment of the ostensibly reactive alkyne moiety. Selected bond lengths and angles summarised in Table 2 . The vinylidene cation $[\mathbf{4 a}]^{+}$(Figure 1) features the expected short $\mathrm{Ru}=\mathrm{C}[1.842(3) \AA]$ and $\mathrm{C}=\mathrm{CH}$ [1.328(4) ̊̊] distances, and linear $\mathrm{Ru}=\mathrm{C}=\mathrm{C}$ fragment $\left[172.2(2)^{\circ}\right]$, consistent with related examples described elsewhere.\{Bruce:2003db, Cowley:2009bs, Bruce:1991ks, Puerta:1999uu, Cowley:2007hj\} The vinylidene ligand deviates slightly from co-planarity with the ene-yne substituent $(\mathrm{C}(1)-\mathrm{C}(2)-\mathrm{C}(3)-\mathrm{C}(4)$ $\left.26.3(3)^{\circ}\right)$; the orientation of vinylidene ligands relative to the half-sandwich 
fragment has been discussed on previous occasions.\{Beddoes:1995en, Lancashire:2011fq\} Although relatively free rotation of the vinylidene complex around the $\mathrm{C}(2)-\mathrm{C}(3)$ bond might be anticipated given the significant single-bond character (C(2)-C(3) 1.475(3) Å), the larger steric effects of the $C(81)$ phenyl ring compared with the $\mathrm{C}(4) \equiv \mathrm{C}(5) \mathrm{H}$ ethynyl fragment leads to the half-sandwich group adopting a position s-cis with respect to $C(4) \equiv C(5)$. It is likely that the further formation of both the initial $\pi$-complex and subsequent rearrangement to the bis(vinylidene) expected on reaction of [4a] ${ }^{+}$with $\mathrm{RuCl}\left(\mathrm{PPh}_{3}\right)_{2} \mathrm{Cp}$ are disfavoured on steric grounds.

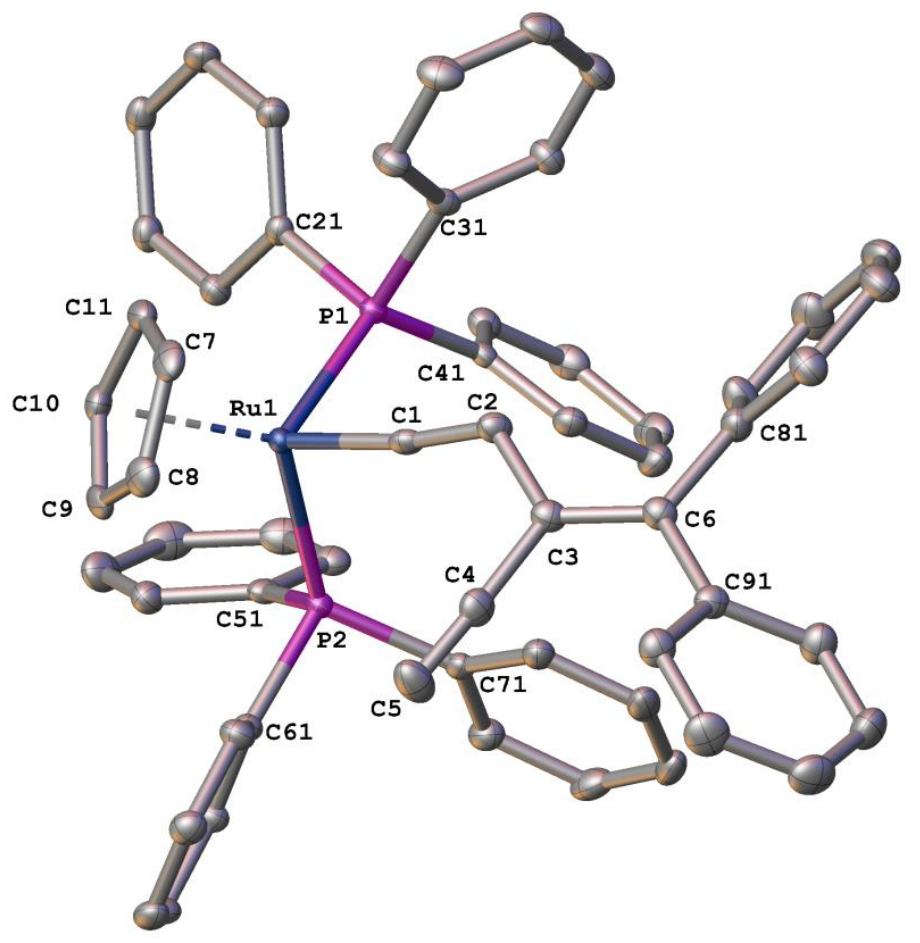

Figure 1 A plot of the cation $[4 \mathbf{4 a}]^{+}$from the crystallographically determined structure of [4a]PF6. Hydrogen atoms have been removed for clarity. Ellipsoids are plotted at $50 \%$.

Similar arguments can be invoked from the acetylide complex $\mathbf{5 a}$ (Figure 2). The formal bond orders within the cross-conjugated ligand are reflected in the $\mathrm{C}(1) \equiv \mathrm{C}(2)(1.2202(2) \AA), \mathrm{C}(2)-\mathrm{C}(3)(1.430(2) \AA), \mathrm{C}(3)=\mathrm{C}(6)(1.375(2) \AA), \mathrm{C}(3)-$ $C(4)(1.444(2) \AA)$ and $C(4) \equiv C(5)(1.189(2) \AA)$ bond lengths. It seems probable that 
the combination of the flanking phenyl groups at $\mathrm{C}(6)$ and the metal alkynyl fragment again hinder access of a second $\left\{\mathrm{Ru}\left(\mathrm{PPh}_{3}\right)_{2} \mathrm{Cp}\right\}^{+}$to the $\mathrm{C}(4) \equiv \mathrm{C}(5)$ triple bond and therefore prevent further reaction.

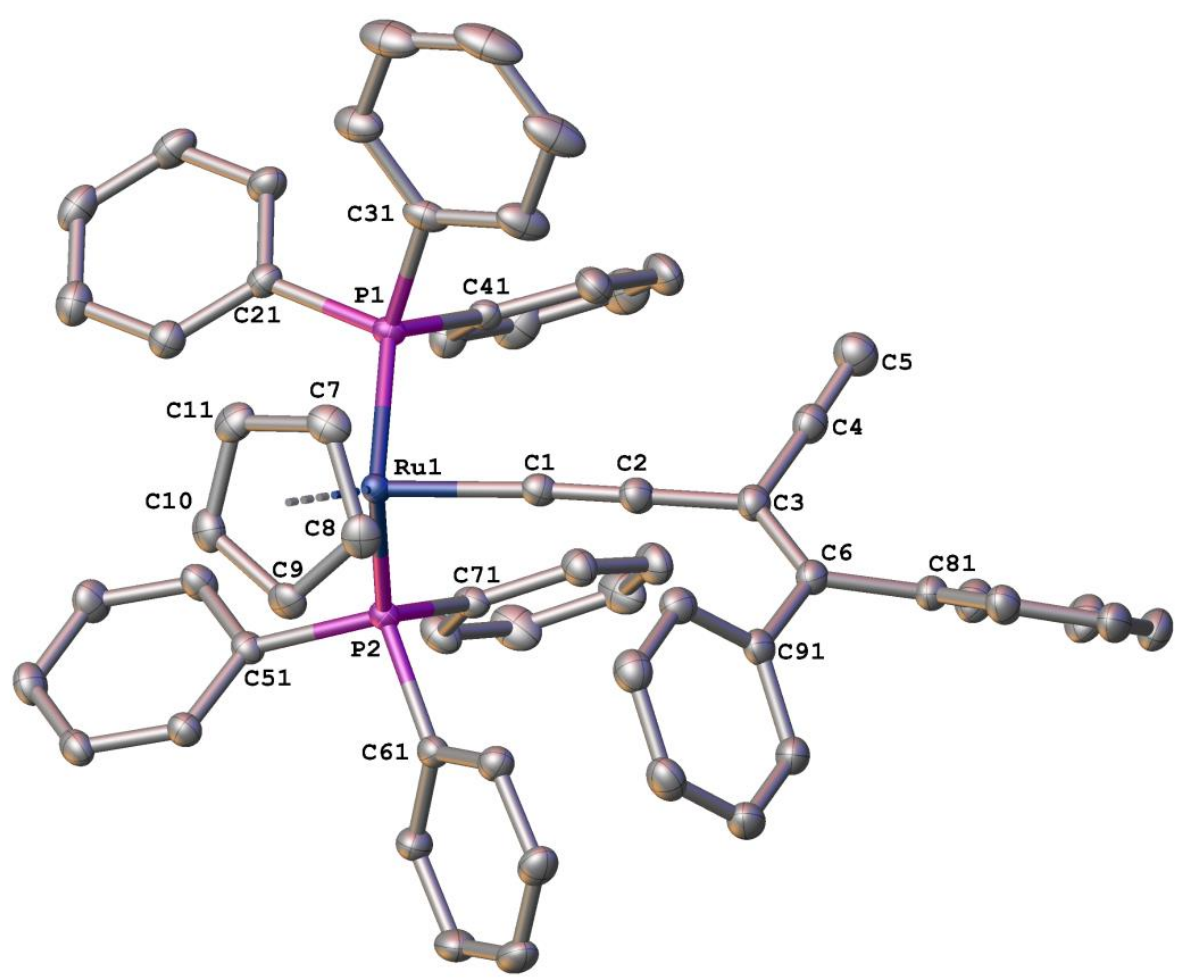

Figure 2 A plot of a molecule of $\mathbf{5 a}$ with hydrogen atoms removed for clarity. Ellipsoids are plotted at $50 \%$.

Given the ready access to 1,1-diethynyl-2,2-diphenyl-ethenes from $\mathbf{1 a}$ an alternative approach to cross-conjugated bi-metallic derivatives was explored. Reaction of 1a with ethynyl ferrocene $(\mathrm{FcC} \equiv \mathrm{CH})$ under the usual cross-coupling conditions gave the bis(ferrocenyl) compound $\mathbf{6 a}$ in moderate (48\%) yield as a bright orange solid (Scheme 2).

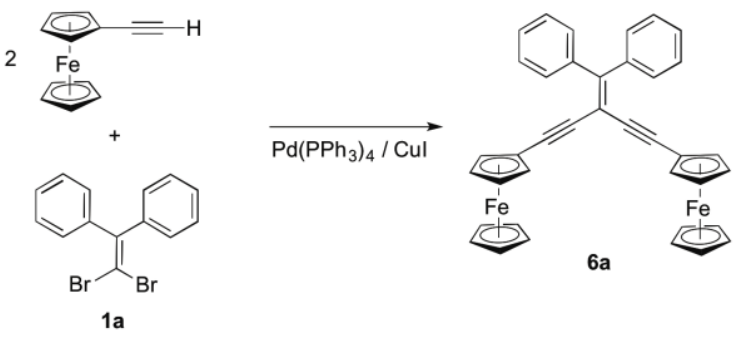

Scheme 2. The preparation of $\mathbf{6 a}$. 
The conversion of ferrocene carboxaldehyde (FcCHO) to 1,1-dibromo-2ferrocenylethene (1b) is known; \{Vincent:2013fd $\}$ most usually $\mathbf{1 b}$ serves as a precursor to both ethynyl ferrocene $(\mathrm{FcC} \equiv \mathrm{CH}),\{$ Courtney:2012uj $\}$ and 1,1diethynyl-2-ferrocenyl ethenes.\{Vincent:2013fd\} The $\mathrm{Pd}(0) / \mathrm{Cu}(\mathrm{I})$ catalysed cross-coupling reactions of $\mathbf{1 b}$ with trimethylsilylacetylene gives $\mathbf{2} \mathbf{b}(76 \%)$, which in turn is readily desilylated to give $\mathbf{3 b}$ (94\%) (Scheme 3). \{Vincent:2013fd In a manner similar to that described for $\mathbf{6} \mathbf{a}$, the cross-coupling of $\mathbf{1 b}$ with ethynyl ferrocene gave the tris(ferrocenyl) complex $\mathbf{6 b}$ (68\%) (Scheme 3).

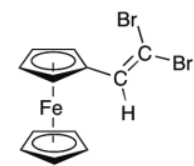

1b
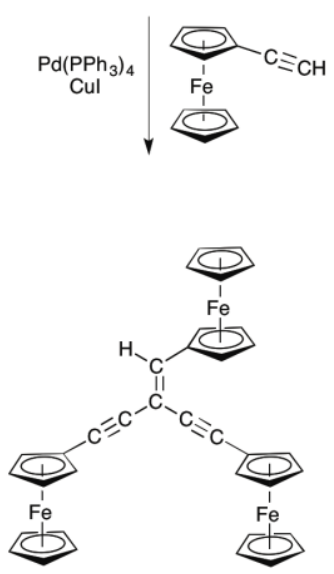

$6 b$

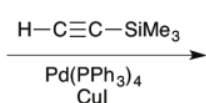

(1)

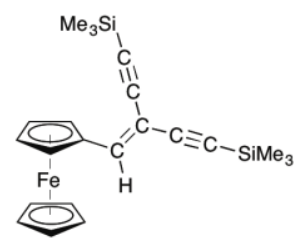

2b

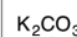

$\mathrm{MeOH}$

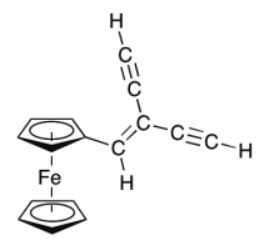

3b

Scheme 3. The preparation of $\mathbf{2 b}, \mathbf{3 b}$ and $\mathbf{6 b}$

In a manner similar to that described above for $\mathbf{3 a}$, reactions of $\mathbf{3 b}$ with one equivalent of $\left[\mathrm{RuCl}\left(\mathrm{PPh}_{3}\right)_{2} \mathrm{Cp}\right]$ and $\mathrm{NH}_{4} \mathrm{PF}_{6}$ gave the mono-vinylidene complex $\left[\mathrm{Ru}\{\mathrm{C}=\mathrm{C}(\mathrm{H}) \mathrm{C}(=\mathrm{CHFc})(\mathrm{C} \equiv \mathrm{CH})\}\left(\mathrm{PPh}_{3}\right)_{2} \mathrm{Cp}\right] \mathrm{PF}_{6}$, but which proved to be unstable on deprotonation with $\mathrm{KOBu}^{\mathrm{t}}$. All attempts at reaction of $\mathbf{3 b}$ with excess $\left[\mathrm{RuCl}\left(\mathrm{PPh}_{3}\right)_{2} \mathrm{Cp}\right]$ proved unsuccessful, yielding brightly coloured blue/green compounds that could not be satisfactorily characterised. 
Metallation of $\mathbf{2} \mathbf{b}$ with [ $\left.\mathrm{AuCl}\left(\mathrm{PPh}_{3}\right)\right]$ took place smoothly in methanol solutions of $\mathrm{NaOH}$ to give $\left[\mathrm{FcC}(\mathrm{H})=\mathrm{C}(\mathrm{C} \equiv \mathrm{CAuPPh})_{2}\right](7,71 \%)$, which was characterised by the usual combination of spectroscopic and elemental analytical methods (Scheme 4). The ${ }^{31} \mathrm{P}$ NMR spectrum gave resonances at $\delta 42.20$ and $42.41 \mathrm{ppm}$ corresponding to the inequivalent phosphine ligands, whilst $\mathrm{Au}-\mathrm{C}$ resonances were observed in the ${ }^{13} \mathrm{C}$ NMR spectrum as doublets $U_{\mathrm{CP}}=27 \mathrm{~Hz}$ in each case) at 105.53 and 102.91 ppm. The $v(\mathrm{AuC} \equiv \mathrm{C})\left(2102 \mathrm{~cm}^{-1}\right)$ and $v\left(\mathrm{FcC}=\mathrm{CR}_{2}\right)\left(1481 \mathrm{~cm}^{-1}\right)$ bands in the IR spectrum were also characteristic of 7. Unfortunately, despite the success of transmetallation reactions between gold acetylide complexes and half-sandwich iron and ruthenium complexes,\{Khairul:2009hk $\}$ reactions of $\mathbf{7}$ with $\left[\mathrm{RuCl}\left(\mathrm{PPh}_{3}\right)_{2} \mathrm{Cp}\right]$ or $\left[\mathrm{RuCl}(\mathrm{dppe}) \mathrm{Cp}^{*}\right]$ failed to yield the desired acetylide complexes.

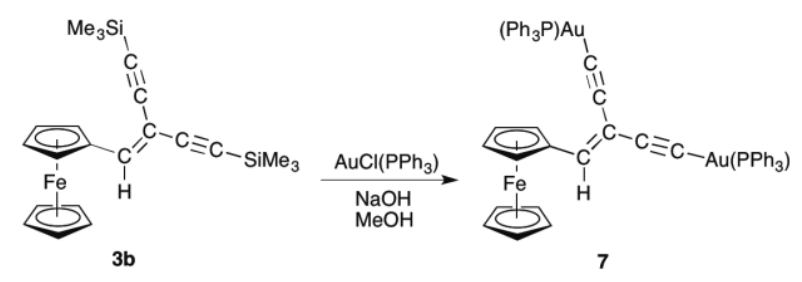

Scheme 4 . The preparation of 7.

Single crystals of the tris(ferrocenyl) complex $\mathbf{6 b}$ suitable for X-ray diffraction were obtained by slow evaporation of a dichloromethane solution (Figure 3). Pertinent bond lengths and angles are given in Table 1. As expected, the 1,1dialkynyl ethene portion of the molecule is essentially planar, with key $\mathrm{C}=\mathrm{C}$

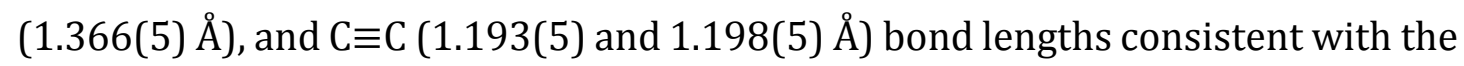
formal valence bond description. There is no evidence from the bond lengths for any substantive difference in conjugation between the ferrocene moieties along the cis- or trans- ene-yne pathways. 


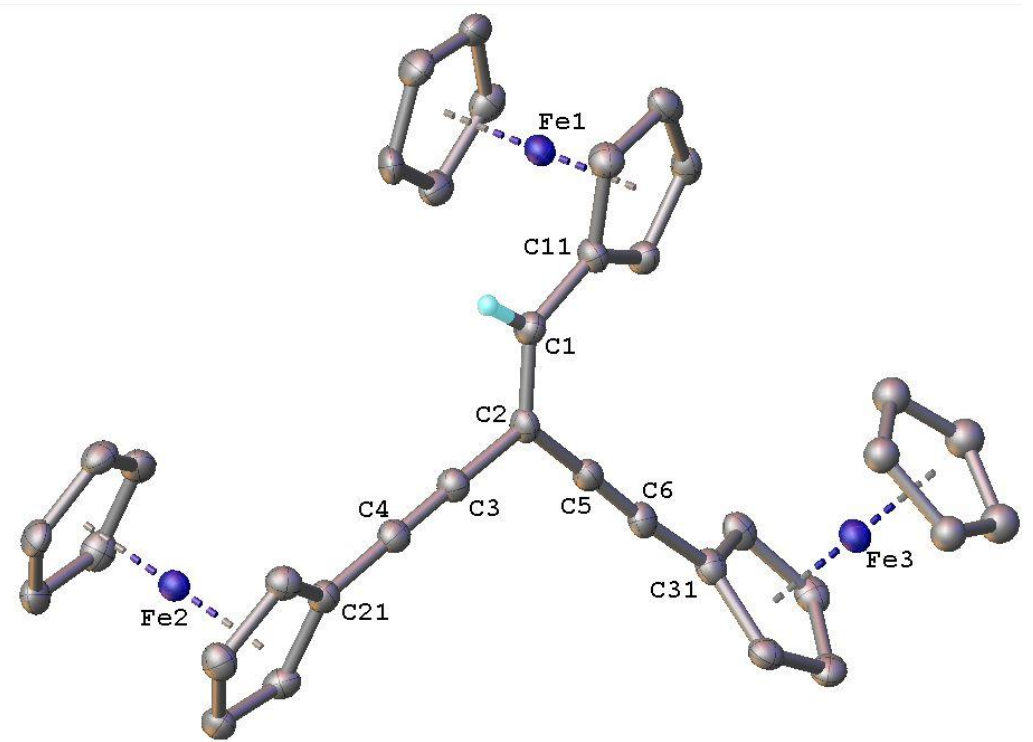

Figure 3. A plot of the molecular structure of $\mathbf{6 b}$, selected hydrogen atoms removed, showing the atom labeling scheme (thermal ellipsoids plotted at $50 \%$ ).

Table 1. Bond lengths $(\AA)$ and angles (deg) from the crystal structure of $\mathbf{6 b}$.

\begin{tabular}{llll}
\hline C11-C1-C2 & $128.2(3)$ & C1-C11 & $1.454(5)$ \\
C1-C2-C3 & $120.0(3)$ & C11-C15 & $1.435(5)$ \\
C1-C2-C5 & $124.1(3)$ & C1-C2 & $1.366(5)$ \\
C2-C3-C4 & $178.5(4)$ & C2-C3 & $1.437(5)$ \\
C2-C5-C6 & $176.2(4)$ & C3-C4 & $1.193(5)$ \\
C3-C4-C21 & $179.5(4)$ & C4-C21 & $1.425(5)$ \\
C5-C6-C31 & $175.7(4)$ & C2-C5 & $1.431(5)$ \\
& & C5-C6 & $1.198(5)$ \\
& & C6-C31 & $1.431(5)$ \\
\hline
\end{tabular}

The redox chemistry of $\mathbf{6 a}$ and $\mathbf{6} \mathbf{b}$ was explored by cyclic voltammetry in a dichloromethane solution containing $10^{-1} \mathrm{M} n$-Bu4NX as the supporting electrolyte $\left(\mathrm{X}=\left[\mathrm{PF}_{6}\right]\right.$ or $\left[\mathrm{B}\left\{\mathrm{C}_{6} \mathrm{H}_{3}\left(\mathrm{CF}_{3}\right)_{2}-3,5\right\}_{4}\right]\left(\left[\mathrm{BAr}_{4}\right]\right)$ (Table 2, Figure 4). When the more strongly ion-pairing or associating electrolyte is employed $\left(\mathrm{X}=\left[\mathrm{PF}_{6}\right]\right)$, the voltammogram of $\mathbf{6 a}$ exhibits a single, chemically reversible electrochemical process. The anodic-to-cathodic peak separation $\left(\Delta E_{\mathrm{p}}(1)\right)$ for this wave approaches twice that of the internal ferrocene/ferrocenium reference couple (Table 2), consistent with the overlapped one-electron processes of the two 
ethynyl ferrocenyl moieties. In the same electrolyte, the tris(ferrocenyl) complex 6b shows two close lying waves, with apparent peak currents approximately in the ratio 1:2 suggesting that the vinyl-ferrocene fragment undergoes oxidation at a measurably different potential than the two (electrochemically indistinguishable) ethynyl-ferrocene moieties (Table 2, Figure 4). The reversible, apparently one electron, oxidation can be further assigned on the basis of comparison with the potentials observed for oxidation of $\mathrm{FcCH}=\mathrm{C}(\mathrm{C} \equiv \mathrm{CR})_{2}$ complexes structurally related to the vinyl-ferrocene moiety.\{Vincent:2013fd $\}$ The second redox wave is assigned to the overlapping oxidation processes of the two ethynylferrocene groups, with the $\Delta E_{\mathrm{p}}$ of this wave approaching twice that of the internal reference and a halfwave potential consistent with that observed for the ethynyl ferrocene moieties in complex $\mathbf{6 a}$ (Table 2).

Cyclic voltammograms obtained from solutions of an electrolyte containing the weakly coordinating anion $\left[\mathrm{BAr}^{\mathrm{F}}\right]^{-}$exhibit greater separation of the individual redox processes of $\mathbf{6 a}$ and $\mathbf{6 b}$. This observation is consistent with results from other poly(ferrocene) compounds in electrolytes containing weakly coordinating anions, \{Barriere:2002iv, Diallo:2011bw, Diallo:2009cf, Gluyas:2014hz $\}$ with an increase in separation of the individual redox events to give two (6a) or three (6b) reversible, one electron process that can be attributed sequential oxidation of the two ethynylferrocene fragments (6a) or the vinyl and two ethynylferrocenyl fragments (6b). The greater separation of the redox processes separation in the voltammetric experiments conducted with the weakly coordinating [BArF $]^{-}$ anion, and hence larger comproportionation constant $K_{\mathrm{C}}$ (Table 2), suggested that there would be a better prospect of observing the individual charge states of each complex in spectroelectrochemical experiments when the appropriate electrolyte was employed. 

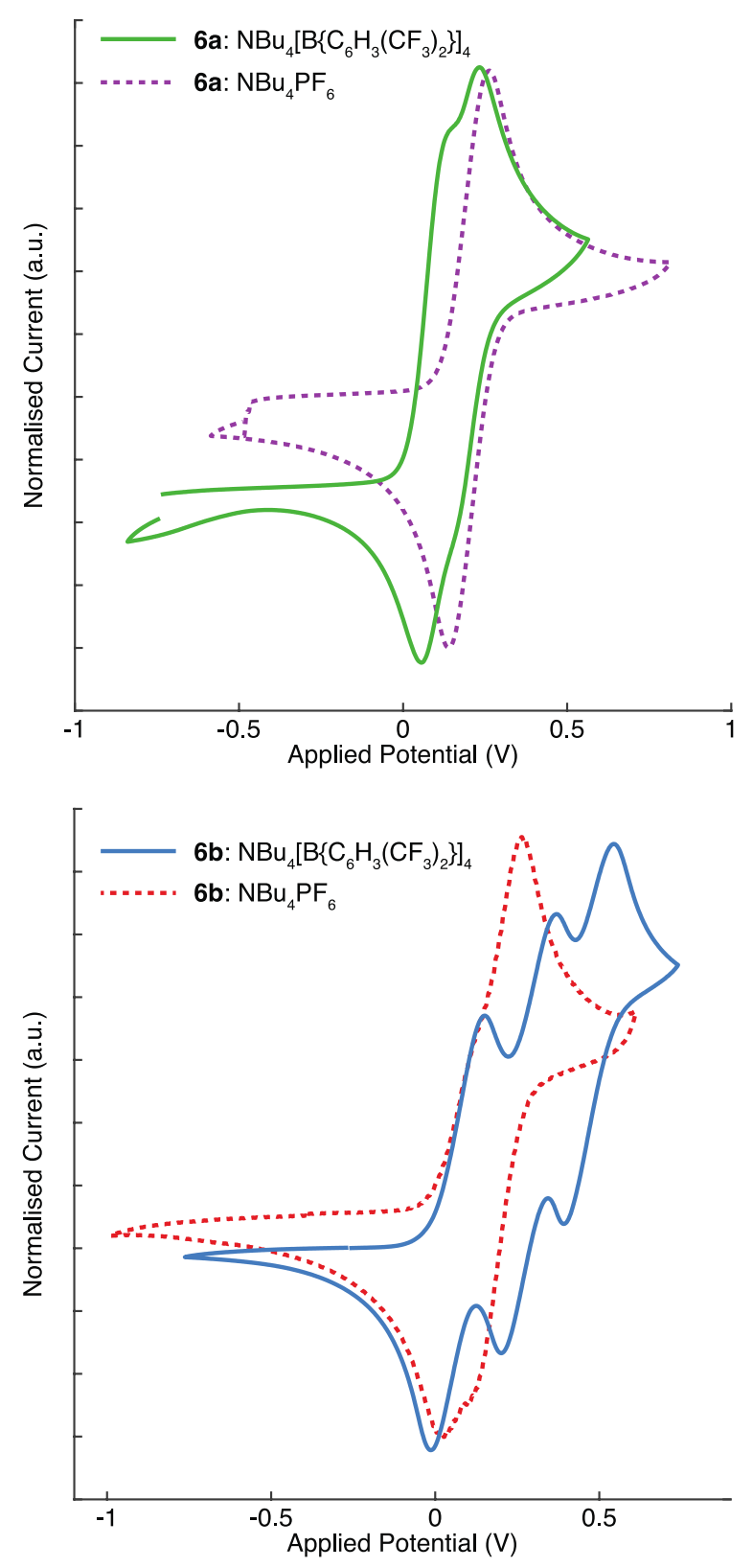

Figure 4. Cyclic voltammetry of $\mathbf{6 a}$ (upper) $\mathbf{6 b}$ (lower) in $\mathrm{CH}_{2} \mathrm{Cl}_{2}$ solution containing $10^{-1} \mathrm{M} n$-Bu $4 \mathrm{NX}$ as the supporting electrolyte $\left(\mathrm{X}=\left[\mathrm{PF}_{6}\right]\right.$ (dotted lines) or $\left[\mathrm{B}\left\{\mathrm{C}_{6} \mathrm{H}_{3}\left(\mathrm{CF}_{3}\right)_{2}-3,5\right\}_{4}\right]$ (solid lines)), 
Table 2. Electrochemical data from $\mathbf{6 a}$ and $\mathbf{6 b}$ in a dichloromethane solution containing $10^{-1} \mathrm{M} n-\mathrm{Bu}_{4} \mathrm{NX}$ as the supporting electrolyte $\left(\mathrm{X}=\left[\mathrm{PF}_{6}\right]\right.$ or $\left.\left[\mathrm{B}\left\{\mathrm{C}_{6} \mathrm{H}_{3}\left(\mathrm{CF}_{3}\right)_{2}-3,5\right\} 4\right]\right)$

\begin{tabular}{lllll}
\hline \multicolumn{3}{c}{$\mathbf{6 a}$} & \multicolumn{3}{c}{$\mathbf{6 b}$} \\
\hline $\mathrm{X}$ & {$\left[\mathrm{PF}_{6}\right]$} & {$\left[\mathrm{BAr}_{4}\right]^{-}$} & {$\left[\mathrm{PF}_{6}\right]$} & {$\left[\mathrm{BAr}_{4}\right]^{-}$} \\
$E_{1 / 2}(1) / \mathrm{V}$ & 0.202 & 0.089 & $0.057^{\mathrm{a}}$ & 0.074 \\
$E_{1 / 2}(2) / \mathrm{V}$ & & 0.201 & $0.202^{\mathrm{a}}$ & 0.290 \\
$E_{1 / 2}(3) / \mathrm{V}$ & & & & 0.471 \\
\hline
\end{tabular}

\begin{tabular}{lllll}
\hline$\Delta \mathrm{E}(1-2) / \mathrm{V}$ & $<0.050$ & 0.112 & 0.145 & 0.216 \\
$K_{\mathrm{c}}$ & 4 & 78 & 283 & 4500 \\
$\Delta \mathrm{E}(2-3) / \mathrm{V}$ & & & & 0.181 \\
$K_{\mathrm{c}}$ & & & & 1151
\end{tabular}

a from differential pulse voltammetry by the method of Taube and Richardson.\{Richardson:1981ul\}

Spectroelectrochemical investigations were undertaken in order to better assess the interactions between the ferrocenyl moieties in $\mathbf{6 a}$ and $\mathbf{6 b}$. Spectroelectrochemical measurements were carried out in $\mathrm{CH}_{2} \mathrm{Cl}_{2}$ solutions containing $10^{-1} \mathrm{M} n-\mathrm{Bu}_{4} \mathrm{~N}\left[\mathrm{~B}\left\{\mathrm{C}_{6} \mathrm{H}_{3}\left(\mathrm{CF}_{3}\right)_{2}-3,5\right\}_{4}\right]$ as supporting electrolye to maximize the thermodynamic stability of the individual redox states with respect to redox disproportionation.

The IR spectra of the bis(ferrocenyl) compound $[6 \mathbf{6}]^{\mathrm{n}+}(\mathrm{n}=0-2)$ give rise to a $v(\mathrm{C} \equiv \mathrm{C})$ band envelope which steadily increases in intensity over the course of the two oxidation steps (Figure 5). The asymetrically-shaped band envelopes of [6a $]^{\text {n+ }}$ display unresolved shoulders indicative of multiple, overlapping $v(C \equiv C)$ bands. The $v(\mathrm{C}=\mathrm{C})$ band at $1481 \mathrm{~cm}^{-1}$ is unaffected by the change in the oxidation state, while a new electronic absorption band grows at ca. $4150 \mathrm{~cm}^{-1}$ consistent with the localized d-d transition of ferrocenium. \{Vincent:2016wb\}\{Gray:1971fo\} 


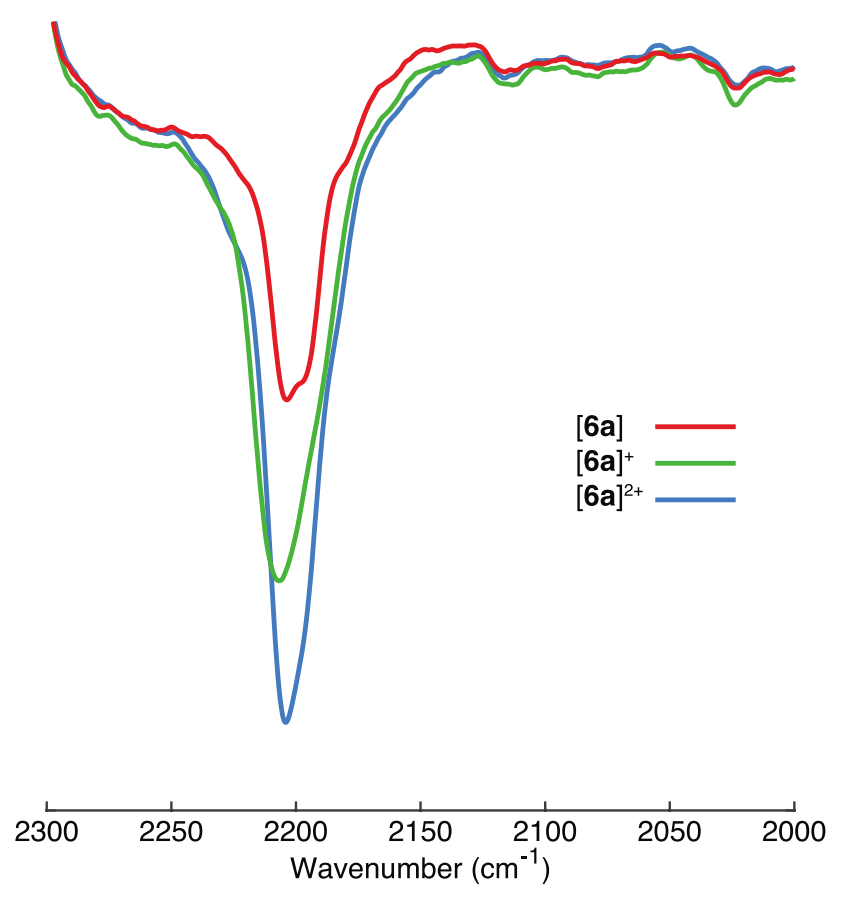

Figure 5. Reversible IR spectral changes in the $v(\mathrm{C} \equiv \mathrm{C})$ region accompanying oxidation of the ferrocenyl moieties of $[6 \mathbf{6 a}]^{\mathrm{n}+}$ in $\mathrm{CH}_{2} \mathrm{Cl}_{2} / 10^{-1} \mathrm{M} \mathrm{n}-\mathrm{Bu}_{4} \mathrm{~N}$ $\left[\mathrm{B}\left\{\mathrm{C}_{6} \mathrm{H}_{3}\left(\mathrm{CF}_{3}\right)_{2}-3,5\right\}_{4}\right]$ within an OTTLE cell.

The IR spectra of complex $[\mathbf{6 b}]^{\mathrm{n}+}(\mathrm{n}=0-3$, Figure 6) exhibit very weak $v(\mathrm{C} \equiv \mathrm{C})$ bands in the neutral $(n=0)$ and monocationic $(n=1)$ species. As oxidation proceeds, the band envelope becomes more intense, although the appearance of this broad, structured band envelope differs little between the di and tri $(n=2,3)$ cationic states (Figure 6, Table 3). Again, the vinyl $v(C=C)\left(1552 \mathrm{~cm}^{-1}\right)$ is unchanged as a function of the redox state of the molecule and ferrocenium based electronic transitions are observed at ca. $4150 \mathrm{~cm}^{-1}$. A comparison of the trends in intensity of the $v(C \equiv C)$ bands as a function of oxidation state change in $6 \mathbf{a}$ and $\mathbf{6 b}$ is consistent with the initial oxidation of the vinyl ferrocene moiety drawn from the electrochemical data above. Further examination of the NIR region failed to identify any electronic transition that could be uniquely associated with the mixed-valence states $[6 \mathbf{6 a}]^{+},[\mathbf{6 b}]^{+}$and $[\mathbf{6 b}]^{2+}$, and therefore these systems are described as Class I systems in the framework of the Robin-Day classification scheme. This behaviour parallels that of other multi-ferrocene complexes such as the tetraferrocenyl(nickel dithiolene) complex studied in the Geiger group.\{Barriere:2002iv\} 


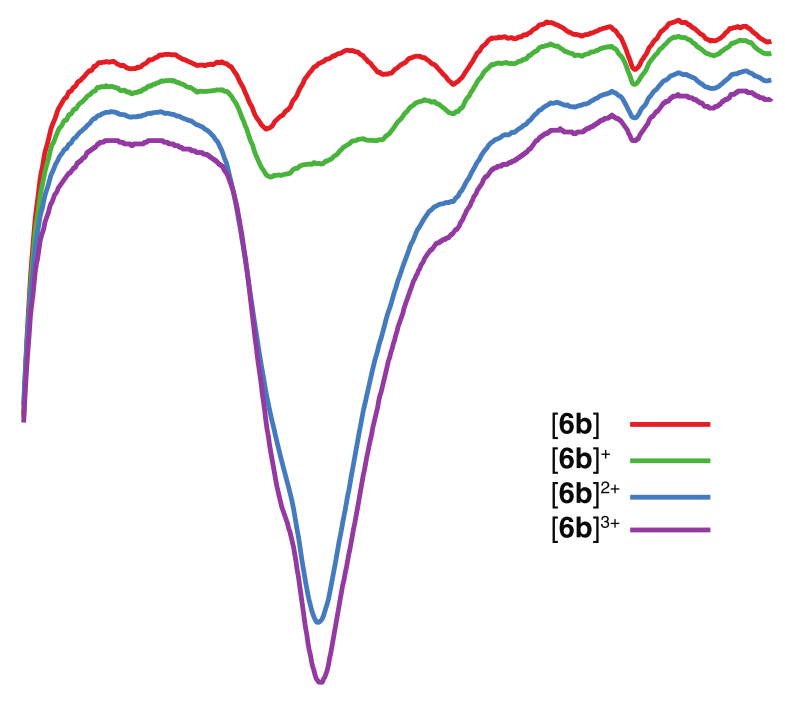

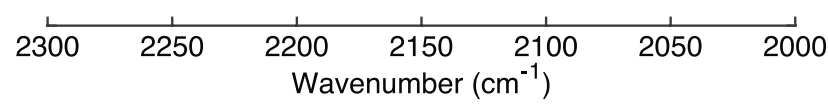

Figure 6. Reversible IR spectral changes in the $v(\mathrm{C} \equiv \mathrm{C})$ region accompanying oxidation of the ferrocenyl moieties of $[6 \mathbf{b}]^{\mathrm{n}+}$ in $\mathrm{CH}_{2} \mathrm{Cl}_{2} / 10^{-1} \mathrm{M} n-\mathrm{Bu} 4 \mathrm{~N}$ $\left[\mathrm{B}\left\{\mathrm{C}_{6} \mathrm{H}_{3}\left(\mathrm{CF}_{3}\right)_{2}-3,5\right\}_{4}\right]$ within an OTTLE cell.

Table 3. IR $v(\mathrm{C} \equiv \mathrm{C}) / \mathrm{cm}^{-1}$ data for $[\mathbf{6 a}]^{\mathrm{n}+}$ and $[\mathbf{6 b}]^{\mathrm{n}+}$ obtained spectroelectrochemically in $\mathrm{CH}_{2} \mathrm{Cl}_{2} / 10^{-1} \mathrm{M} n-\mathrm{Bu} 4 \mathrm{~N}\left[\mathrm{~B}\left\{\mathrm{C}_{6} \mathrm{H}_{3}\left(\mathrm{CF}_{3}\right)_{2}-3,5\right\} 4\right]$ within an OTTLE cell.

\begin{tabular}{lrr}
\hline $\mathrm{n}$ & {$[\mathbf{6 a}]^{\mathrm{n}+}$} & {$[\mathbf{6 b}]^{\mathrm{n}+}$} \\
\hline 0 & $2203(\mathrm{~s})$ & $2203(\mathrm{~s})$ \\
& $2198(\mathrm{~s})$ & - \\
1 & $2204(\mathrm{~s})$ & $2201(\mathrm{~s})$ \\
& $2198(\mathrm{sh})$ & $2178(\mathrm{sh})$ \\
2 & $2206(\mathrm{~s})$ & $2180(\mathrm{~s})$ \\
& $2192(\mathrm{sh})$ & $2201(\mathrm{sh})$ \\
3 & - & $2180(\mathrm{~s})$ \\
& - & $2199(\mathrm{sh})$ \\
\hline
\end{tabular}




\section{Conclusion}

The monometallic ethynyl-vinylidene complex $\left[\mathrm{Ph}_{2} \mathrm{C}=\mathrm{C}(\mathrm{C} \equiv \mathrm{CH})\left\{\mathrm{C}(\mathrm{H})=\mathrm{CRu}\left(\mathrm{PPh}_{3}\right)_{2} \mathrm{Cp}\right\}\right] \mathrm{PF}_{6}\left([\mathbf{4 a}] \mathrm{PF}_{6}\right)$ and the related ethynylalkynyl complex $\mathrm{Ph}_{2} \mathrm{C}=\mathrm{C}(\mathrm{C} \equiv \mathrm{CH})\left\{\mathrm{C} \equiv \mathrm{CRu}\left(\mathrm{PPh}_{3}\right)_{2} \mathrm{Cp}\right\} \quad$ (5a) were successfully prepared from $\mathrm{Ph}_{2} \mathrm{C}=\mathrm{C}(\mathrm{C} \equiv \mathrm{CH})_{2}$ (3a) and characterised. However, analogous compounds derived from the more electron-rich ligand precursor $\left[\mathrm{FcCH}=\mathrm{C}(\mathrm{C} \equiv \mathrm{CH})_{2}\right]$ (3b) proved to be unstable during work-up. Furthermore, attempts to prepare bis(ruthenium) complexes from $\mathbf{3 a}$ and $\mathbf{3 b}$ or from transmetallation reactions of the bis(alkynylgold) complex $\mathrm{FcCH}=\mathrm{C}\left(\mathrm{C} \equiv \mathrm{CAuPPh}_{3}\right)_{2}(7)$ with $\mathrm{RuCl}\left(\mathrm{PPh}_{3}\right)_{2} \mathrm{Cp}$ were unsuccessful. Instead, bisand tris(ferrocenyl) compounds $\mathrm{Ph}{ }_{2} \mathrm{C}=\mathrm{C}(\mathrm{C} \equiv \mathrm{CFc})_{2}(\mathbf{6 a})$ and $\mathrm{FcCH}=\mathrm{C}(\mathrm{C} \equiv \mathrm{CFc})_{2}(\mathbf{6 b})$ were more readily obtained from Sonogashira-like Pd(II) / Cu(I) catalysed crosscoupling reactions of $\mathrm{FcC} \equiv \mathrm{CH}$ with the 1,1-dibromo vinyl complexes $\mathrm{PhC}=\mathrm{CBr}_{2}$ (1a) and $\mathrm{FcC}(\mathrm{H})=\mathrm{CBr}_{2}(\mathbf{1 b})$. Analysis of the multi-ferrocene compounds $\mathbf{6 a}$ and $\mathbf{6 b}$ by cyclic voltammetry in $\mathrm{CH}_{2} \mathrm{Cl}_{2}$ solutions containing $n$-Bu $\mathrm{NPF}_{6}$ or $n$-Bu $4 \mathrm{NBArF}_{4}$ as supporting electrolyte indicates a significant contribution from electrostatic effects to the separation of the individual ferrocene-based redox processes, and hence better resolution of the individual electrochemical processes in the electrolyte featuring the more weakly coordinating anion, $\left[\mathrm{BAr}_{4}\right]^{-}$. The trends in the electrochemical potentials and the IR spectroelectrochemical response of $6 \mathbf{6}$ and $\mathbf{6 b}$ indicate the vinyl ferrocene moiety in $\mathbf{6 b}$ undergoes oxidation before the ethynyl ferrocene fragments. There is no evidence of electronic coupling between the metallocene moieties and $[6 \mathbf{6}]^{+},[6 \mathbf{b}]^{\mathrm{n}+}(\mathrm{n}=1,2)$ are best described as Class I mixed-valence compounds. Efforts to reduce the steric bulk of the half-sandwich metal fragment (e.g. $\mathrm{Ru}(\mathrm{dppe}) \mathrm{Cp}, \mathrm{Ru}\left(\mathrm{PMe}_{3}\right)_{2} \mathrm{Cp}$ ) or alter the orientation of the intermediate vinylidenes (e.g. $\mathrm{Mo}(\mathrm{dppe})\left(\eta-\mathrm{C}_{7} \mathrm{H}_{7}\right)$ ) to promote further metallation of the cross-conjugated ligand will form the basis of future work.

\section{Experimental Section}

General Conditions All reactions were carried out under an atmosphere of dry nitrogen using standard Schlenk techniques. Reaction solvents were dried and distilled or purified by passage through an Innovative Technologies SPS-400 
solvent purification system, and degassed before use. Other solvents were standard reagent grade and used as received. No special precautions were taken to exclude air or moisture during workup except where otherwise indicated. The compounds [RuCl(PPh$\left.)_{2} \mathrm{Cp}\right],\{$ Bruce:1990ed\} 1,1,-dibromo-2,2-diphenyl ethene (1a),\{Donovan:2004dj\} 1,1-dibromo-2-ferrocenyl ethene (1b),\{Vincent:2013fd $\}$ 1,1-bis(trimethylsilylethynyl)-2,2-diphenyl-ethene (2a),\{Barnes:2013cg\} 1,1bis(trimethylsilylethynyl)-2-ferrocenyl-ethene (2b),\{Vincent:2013fd $\}$ 1,1bis(ethynyl)-2,2-diphenyl-ethene (3a)\{Barnes:2013cg\} and [1,1-bis(ethynyl)-2ferrocenyl-ethene (3b)\{Vincent:2013fd $\}$ were prepared by literature routes. Ethynyl ferrocene $(\mathrm{FcC} \equiv \mathrm{CH})$ was synthesised from 1b,\{Courtney:2012uj\} $\left[\mathrm{AuCl}\left(\mathrm{PPh}_{3}\right)\right]$ from $\mathrm{H}\left[\mathrm{AuCl}_{4}\right] \quad\{$ Bruce:1989jn $\}$ and $\left[\mathrm{Pd}\left(\mathrm{PPh}_{3}\right)_{4}\right]$ from $\mathrm{PdCl}_{2}$. Coulson:1972hh\} Carbon tetrabromide $\left(\mathrm{CBr}_{4}\right)$ was sublimed before use. All other reagents were commercially available and used as received. NMR spectra were recorded at $23{ }^{\circ} \mathrm{C}$ on a Varian NMR Systems 700 spectrometer using $\mathrm{CD}_{2} \mathrm{Cl}_{2}$ as the solvent. Chemical shifts were determined relative to internal solvent signals, $\{$ Gottlieb:1997hm, Fulmer:2010bk $\}$ or external $85 \% \mathrm{H}_{3} \mathrm{PO}_{4}(\delta=0.00 \mathrm{ppm})$. Assignment of the ${ }^{1} \mathrm{H}$ and ${ }^{13} \mathrm{C}$ NMR data was supported by gradient selected ${ }^{13} \mathrm{C}$, ${ }^{1} \mathrm{H}$ HMQC and HMBC experiments. ASAP-MSi spectra were recorded from solid aliquots on an LCT Premier XE mass spectrometer (Waters Ltd., U.K.) or Xevo QToF mass spectrometer (Waters Ltd., U.K.) in which the aliquot is vaporised using hot $\mathrm{N}_{2}$, ionized by a corona discharge, and carried to the TOF detector (working range $m / z$ 100-1000). A melting point tube was dipped in to a sample solution $(\sim 1 \mathrm{mg} / \mathrm{mL})$ and introduced into the spectrometer, where a temperature ramp from $50{ }^{\circ} \mathrm{C}$ to $450{ }^{\circ} \mathrm{C}$ vaporises the sample enabling atmospheric pressure chemical ionisation (APCI) to occur. MS data is processed using MassLynx 4.1.

Cyclic voltammetry was carried out using an EcoChemie Autolab PG-STAT 30 or a Palm Instruments EmStat2 potentiostat, with a platinum disc working electrode, a platinum wire counter electrode, and a platinum wire pseudo-reference electrode, from solutions in dichloromethane containing either $0.1 \mathrm{M} n$-Bu4NPF6 or $\left.\quad 0.1 \mathrm{M} \quad n-\mathrm{Bu} 4 \mathrm{~N}\left[\mathrm{~B}\left\{\mathrm{C}_{6} \mathrm{H}_{3}\left(\mathrm{CF}_{3}\right)_{2}-3,5\right\}\right]_{4} \quad\left(n-\mathrm{Bu}_{4} \mathrm{NBAr}^{\mathrm{F}}\right)\right)$ as the electrolyte. Measurements with $v=100,200,400$ and $800 \mathrm{mV} . \mathrm{s}^{-1}$ showed that the ratio of the anodic to cathodic peak currents varied linearly as a function of the square root of 
scan rate in all cases. The decamethylferrocene/decamethylferrocinium $\left(\mathrm{FeCp}_{2}{ }_{2} /\left[\mathrm{FeCp}_{2}\right]^{+}\right)$couple was used as an internal reference for potential measurements such that the couple falls at $-0.55 \mathrm{~V}\left(\mathrm{CH}_{2} \mathrm{Cl}_{2} / n-\mathrm{Bu}_{4} \mathrm{NPF}_{6}\right)$ or $0.62 \mathrm{~V}\left(\mathrm{CH}_{2} \mathrm{Cl}_{2} / n-\mathrm{Bu}_{4} \mathrm{NBAr}_{4}\right)$ relative to external $\mathrm{FeCp}_{2} /\left[\mathrm{FeCp}_{2}\right]^{+}$at

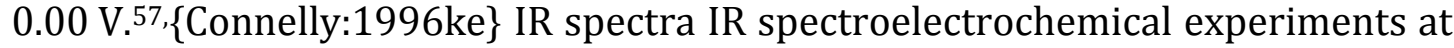
room temperature were recorded on a Bruker Vertex 70v FT-IR with an OTTLE cell equipped with a Pt-minigrid working electrode and $\mathrm{CaF}_{2}$ windows.\{Krejcik:1991cv\} The optical path of the cell was ca. $0.2 \mathrm{~mm}$. The concentrations of the ferrocenyl compounds and the supporting electrolyte ( $n$ $\mathrm{Bu}_{4} \mathrm{NBAr}^{\mathrm{F}} 4$ ) used in these measurements were $1.3 \times 10^{-2}$ and $3 \times 10^{-1} \mathrm{~mol} \mathrm{dm}^{-3}$, respectively. Elemental analyses were performed at the London Metropolitan University.

\section{Preparation of $\left[\mathrm{Ru}\left\{\mathrm{C}=\mathrm{C}(\mathrm{H}) \mathrm{C}(\mathrm{C} \equiv \mathrm{CH})=\mathrm{CPh}_{2}\right\}\left(\mathrm{PPh}_{3}\right)_{2} \mathrm{Cp}\right] \mathrm{PF}_{6}\left([4 \mathrm{a}] \mathrm{PF}_{6}\right)$}

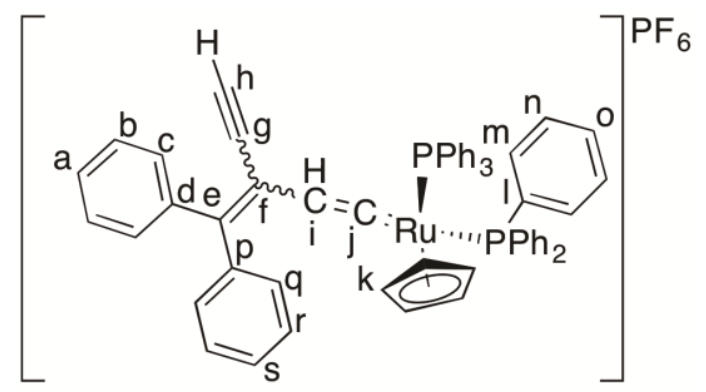

A solution of 3a (100 mg, $0.438 \mathrm{mmol}),\left[\mathrm{RuCl}\left(\mathrm{PPh}_{3}\right)_{2} \mathrm{Cp}\right]$ (286 mg, $\left.0.394 \mathrm{mmol}\right)$ and $\mathrm{KPF}_{6}(81 \mathrm{mg}, 0.438 \mathrm{mmol})$ in $\mathrm{CH}_{2} \mathrm{Cl}_{2}(15 \mathrm{ml})$ was heated at reflux point for 20 hours. The solution was allowed to cool, concentrated in vacuo to ca. $2 \mathrm{ml}$ and then added drop-wise to vigorously stirred, ice-cold diethylether causing precipitation of a pale red solid. The precipitate was collected by filtration, washed with hexanes (3 $55 \mathrm{ml})$ and diethyl ether $(3 \times 5 \mathrm{ml})$ and air dried. Yield $329 \mathrm{mg}, 79 \%$. Crystals suitable for X-ray diffraction were grown by slow diffusion of diethyl ether into a $\mathrm{CH}_{2} \mathrm{Cl}_{2}$ solution of the product. ${ }^{1} \mathrm{H}$ NMR $\left(\mathrm{CD}_{2} \mathrm{Cl}_{2}\right): \delta 3.09\left(1 \mathrm{H}, \mathrm{s}, \mathrm{H}_{h}\right), 4.92(1 \mathrm{H}, \mathrm{t}, J=$ $\left.2.5 \mathrm{~Hz}, \mathrm{H}_{i}\right), 5.23\left(5 \mathrm{H}, \mathrm{s}, \mathrm{H}_{k}\right), 7.02-7.05\left(12 \mathrm{H}, \mathrm{m}, \mathrm{H}_{n}\right), 7.23-7.26\left(15 \mathrm{H}, \mathrm{m}, \mathrm{H}_{m}\right.$ and $\left.\mathrm{H}_{o}\right), 7.29-7.34\left(4 \mathrm{H}, \mathrm{m}, \mathrm{H}_{b}\right.$ and $\mathrm{H}_{r}$ ), $7.40-7.44\left(6 \mathrm{H}, \mathrm{m}, \mathrm{H}_{a}, \mathrm{H}_{c}, \mathrm{H}_{q}\right.$ and $\left.\mathrm{H}_{s}\right) .{ }^{31} \mathrm{P} \mathrm{NMR}$ $\left(\mathrm{CD}_{2} \mathrm{Cl}_{2}\right): \delta 41.62(\mathrm{~s}) .{ }^{13} \mathrm{C}$ NMR $\left(\mathrm{CD}_{2} \mathrm{Cl}_{2}\right): \delta 81.7\left(\mathrm{C}_{g}\right), 84.7\left(\mathrm{C}_{k}\right), 90.7\left(\mathrm{C}_{f}\right), 94.9\left(\mathrm{C}_{i}, \mathrm{t}, J\right.$ $=2 \mathrm{~Hz}), 104.2,118.4,127.8,128.1\left(\mathrm{C}_{b}, \mathrm{C}_{c}, \mathrm{C}_{q}, \mathrm{C}_{r}\right), 128.5\left(\mathrm{C}_{h}\right), 128.6\left(\mathrm{C}_{n}\right.$ or $\mathrm{C}_{o} \mathrm{dd}, J_{\mathrm{CP}}$ 
$\left.=J^{\prime}{ }_{\mathrm{CP}}=5 \mathrm{~Hz}\right), 128.8\left(\mathrm{C}_{n}\right.$ or $\left.\mathrm{C}_{\mathrm{o}} \mathrm{dd}, J_{\mathrm{CP}}=J^{\prime}{ }_{\mathrm{CP}}=5 \mathrm{~Hz}\right), 129.4,130.4,131.1\left(\mathrm{C}_{l}, \mathrm{C}_{a}, \mathrm{C}_{s}\right)$, $133.0\left(\mathrm{C}_{m}, \mathrm{dd},{ }^{2} J_{\mathrm{CP}}={ }^{5} J_{\mathrm{CP}}=5 \mathrm{~Hz}\right), 139.9,140.5,145.9\left(\mathrm{C}_{d}, \mathrm{C}_{p}, \mathrm{C}_{e}\right), \mathrm{C}_{j}$ not detected. MALDI MS(+): $m / z 919.1[\mathrm{M}]^{+}$. IR $\left(\mathrm{CH}_{2} \mathrm{Cl}_{2}\right) v(\mathrm{C} \equiv \mathrm{C}) 2108 \mathrm{~cm}^{-1}, v(\mathrm{CH}=\mathrm{CRu}) 1629$ $\mathrm{cm}^{-1}, v(\mathrm{C}=\mathrm{C}) 1483 \mathrm{~cm}^{-1}$. Found C 66.53, H 4.40 \% required C 66.58, H $4.45 \%$. Crystal data for [4a]PF 6 : $\mathrm{C}_{59} \mathrm{H}_{47} \mathrm{P}_{2} \mathrm{Ru} \times \mathrm{PF}_{6} \times 2 \mathrm{CH}_{2} \mathrm{Cl}_{2}, \mathrm{M}=1233.80$, monoclinic, space group $P 21 / c, a=12.1012(2), b=31.5936(4), c=14.8655(2) \AA, \beta=$ 103.096(2) $)^{\circ}, U=5535.6(1) \AA^{3}, F(000)=2512.0, \mathrm{Z}=4, D_{\mathrm{c}}=1.480 \mathrm{mg} \mathrm{m}^{-3}, \mu=0.623$ $\mathrm{mm}^{-1} .92790$ reflections were collected yielding 14013 unique data $\left(R_{\text {merg }}=\right.$ 0.0549). Final $w R_{2}\left(F^{2}\right)=0.1018$ for all data (678 refined parameters), conventional $R_{1}(F)=0.0443$ for 11904 reflections with $I \geq 2 \sigma$, GOF $=1.093$.

\section{Preparation of cis $/$ trans $-\left[\mathrm{Ru}\{=\mathrm{C}=\mathrm{C}(\mathrm{H}) \mathrm{C}(\mathrm{C} \equiv \mathrm{CH})=\mathrm{CHFc}\}\left(\mathrm{PPh}_{3}\right)_{2} \mathrm{Cp}\right] \mathrm{PF}_{6}$ $\left([\mathbf{4 b}] \mathbf{P F}_{6}\right)$}

A solution of $\mathbf{3 b}(100 \mathrm{mg}, 0.384 \mathrm{mmol})$, [RuCl$\left(\mathrm{PPh}_{3}\right)_{2} \mathrm{Cp}$ ] (252 mg, $\left.0.346 \mathrm{mmol}\right)$ and $\mathrm{KPF}_{6}(71 \mathrm{mg}, 0.384 \mathrm{mmol})$ in $\mathrm{CH}_{2} \mathrm{Cl}_{2}(15 \mathrm{ml})$ was heated at reflux for 16 hours. After this time, the solution was allowed to cool, concentrated in vacuo to ca. $3 \mathrm{ml}$ and filtered through Celite into a rapidly stirred diethyl ether to give a red precipitate. The precipitate was collected by filtration, washed with hexanes $(3 \mathrm{x}$ $5 \mathrm{ml})$ and diethyl ether $(3 \times 5 \mathrm{ml})$ and air dried. Yield $334 \mathrm{mg}, 88 \%$ as a mixture of isomers, which was briefly characterised (MALDI MS(+) $m / z 950.1[\mathrm{M}-\mathrm{H}]^{+}$. IR $\left.\left(\mathrm{CH}_{2} \mathrm{Cl}_{2}\right): v(\mathrm{C} \equiv \mathrm{CH}) 1980 \mathrm{~cm}^{-1}, v(\mathrm{Ru}=\mathrm{C}=\mathrm{C}) 1632 \mathrm{~cm}^{-1} ; v(\mathrm{C}=\mathrm{C}) 1586 \mathrm{~cm}^{-1}\right)$ before being used directly in the attempted preparation of $\mathbf{5 b}$.

Preparation of $\left[\mathrm{Ru}\left\{\mathrm{C} \equiv \mathrm{CC}(\mathrm{C} \equiv \mathrm{CH}) \mathrm{C}=\mathrm{CPh}{ }_{2}\right\}\left(\mathrm{PPh}_{3}\right)_{2} \mathrm{Cp}\right](5 \mathrm{a})$ 


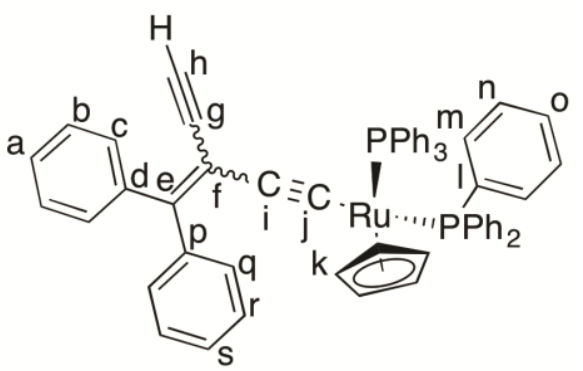

A solution of [4a]PF 6 ( $85 \mathrm{mg}, 0.08 \mathrm{mmol})$ in methanol $(6 \mathrm{ml})$ was treated with $\mathrm{KOBu}^{\mathrm{t}}$ (42 mg, $0.399 \mathrm{mmol}$ ) and the mixture stirred for 10 minutes. The resulting yellow precipitate was collected by filtration, washed with methanol $(3 \times 5 \mathrm{ml})$ and dried in air. Yield $45 \mathrm{mg}, 62 \%$. Crystals suitable for X-ray diffraction were grown by slow diffusion of methanol into a $\mathrm{CH}_{2} \mathrm{Cl}_{2}$ solution of the product. ${ }^{1} \mathrm{H} \mathrm{NMR}$ $\left(\mathrm{CDCl}_{3}\right): \delta 2.77(\mathrm{~s}, 1 \mathrm{H}), 4.22(\mathrm{~s}, 5 \mathrm{H}), 7.05(\mathrm{t}, J=7.6 \mathrm{~Hz}, 12 \mathrm{H}), 7.13(\mathrm{~m}, 2 \mathrm{H}), 7.16(\mathrm{t}, J$ $=7.4 \mathrm{~Hz}, 6 \mathrm{H}), 7.32-7.28(\mathrm{~m}, 4 \mathrm{H}), 7.36(\mathrm{~m}, 2 \mathrm{H}), 7.44-7.39(\mathrm{~m}, 14 \mathrm{H}) .{ }^{13} \mathrm{C} \mathrm{NMR}$ $\left(\mathrm{CDCl}_{3}\right): \delta 85.5\left(\mathrm{C}_{k}\right), 106.2,113.4,126.5,\left(\mathrm{C}_{f}, \mathrm{C}_{g}, \mathrm{C}_{i}\right), 126.6\left(\mathrm{C}_{j}\right), 127.2\left(\mathrm{C}_{n}, \mathrm{dd},{ }^{3} J_{\mathrm{CP}}=\right.$ $\left.{ }^{6} J_{\mathrm{CP}}=5 \mathrm{~Hz}\right), 128.2\left(\mathrm{C}_{o}\right), 128.30\left(\mathrm{C}_{h}\right), 130.0,130.4,130.7,131.0\left(\mathrm{C}_{b}, \mathrm{C}_{c}, \mathrm{C}_{p}, \mathrm{C}_{r}\right), 133.8$ $\left(\mathrm{C}_{m}, \mathrm{dd},{ }^{2} J_{\mathrm{CP}}={ }^{5} J_{\mathrm{CP}}=5 \mathrm{~Hz}\right), 138.6,138.7,138.8\left(\mathrm{C}_{l}, \mathrm{C}_{a}, \mathrm{C}_{s}\right), 142.3,142.4\left(\mathrm{C}_{d}, \mathrm{C}_{p}\right)$, $145.7\left(\mathrm{C}_{e}\right) \cdot{ }^{31} \mathrm{P} \mathrm{NMR}\left(\mathrm{CDCl}_{3}\right): \delta$ 50.35. MALDI MS(+): $m / z$ 918.2 $[\mathrm{M}]^{+}$. IR $\left(\mathrm{CH}_{2} \mathrm{Cl}_{2}\right)$ $v(\mathrm{C} \equiv \mathrm{CH}) 2105 \mathrm{~cm}^{-1}, v(\mathrm{C} \equiv \mathrm{CRu}) 2044 \mathrm{~cm}^{-1}, v(\mathrm{C}=\mathrm{C}) 1482 \mathrm{~cm}^{-1}$.

Crystal data for 5a: $\mathrm{C}_{59} \mathrm{H}_{46} \mathrm{P}_{2} \mathrm{Ru} \times \mathrm{CH}_{2} \mathrm{Cl}_{2}, \mathrm{M}=1002.89$, monoclinic, space group $P$ $21 / n, \mathrm{a}=10.4352(6), b=24.6836(13), c=18.6025(10) \AA, \beta=98.390(1))^{\circ}, U=$ 4740.3(4)) $\AA^{3}, F(000)=2064.0, Z=4, D_{\mathrm{c}}=1.405 \mathrm{mg} \mathrm{m}^{-3}, \mu=0.552 \mathrm{~mm}^{-1} .83912$ reflections were collected yielding 13820 unique data $(R \operatorname{merg}=0.0307)$. Final $w R_{2}\left(F^{2}\right)=0.0792$ for all data (586 refined parameters), conventional $R_{1}(F)=$ 0.0294 for 11966 reflections with $I \geq 2 \sigma, \mathrm{GOF}=1.067$.

\section{Preparation of $\mathrm{Ph}_{2} \mathrm{C}=\mathrm{C}(\mathrm{C} \equiv \mathrm{CFc})_{2}$ (6a)}

Ethynyl ferrocene (652 mg, $3.10 \mathrm{mmol}), \mathbf{1 a}(500 \mathrm{mg}, 1.48 \mathrm{mmol}),\left[\mathrm{Pd}\left(\mathrm{PPh}_{3}\right)_{4}\right]$ (85.0 mg, $73.6 \mu \mathrm{mol})$ and $\mathrm{CuI}(6 \mathrm{mg}, 3.15 \mu \mathrm{mol})$ were dissolved in triethylamine $(25 \mathrm{ml})$. The reaction mixture was heated to reflux for 17 hours, cooled to ambient temperature and the solvent was removed in vacuo. The residue was purified by column chromatography (eluent: hexanes to hexanes/dichloromethane 150:50 $(\mathrm{v} / \mathrm{v})$ ) ) concentration of the relevant fractions afforded $\mathbf{6 a}$ in $47 \%$ yield (418 $\mathrm{mg}$, 
$48 \%)$ as an orange solid. ${ }^{1} \mathrm{H}$ NMR $\left(\mathrm{CD}_{2} \mathrm{Cl}_{2}\right): \delta 4.14\left(5 \mathrm{H}, \mathrm{s}, \mathrm{C}_{5} \mathrm{H}_{5}\right), 4.22\left(2 \mathrm{H}, \mathrm{t},{ }^{3} \mathrm{~J}_{\mathrm{H}-\mathrm{H}}\right.$ $\left.=2 \mathrm{~Hz}, \mathrm{C}_{5} \mathrm{H}_{4} \mathrm{C} \equiv \mathrm{C}\right), 4.36\left(2 \mathrm{H}, \mathrm{t}, 3_{\mathrm{H}-\mathrm{H}}=2 \mathrm{~Hz}, \mathrm{C}_{5} H_{4} \mathrm{C} \equiv \mathrm{C}\right), 7.37-7.43\left(6 \mathrm{H}, \mathrm{m}, o-\mathrm{C}_{6} H_{5} / p-\right.$ $\left.\mathrm{C}_{6} \mathrm{H}_{5}\right), 7.53\left(4 \mathrm{H}, \mathrm{m}, m-\mathrm{C}_{6} \mathrm{H}_{5}\right) .{ }^{13} \mathrm{C} \mathrm{NMR}\left(\mathrm{CD}_{2} \mathrm{Cl}_{2}\right): \delta 65.2\left(\mathrm{C}-1, \mathrm{C}_{5} \mathrm{H}_{4}\right), 69.4(\mathrm{C}-3 / \mathrm{C}-5$, $\left.C_{5} \mathrm{H}_{4}\right), 70.3\left(\mathrm{C}_{5} \mathrm{H}_{5}\right), 71.6\left(\mathrm{C}-2 / \mathrm{C}-5, C_{5} \mathrm{H}_{4}\right), 85.1\left(\mathrm{C} \equiv C\right.$ or $\left.\left(\mathrm{C}_{6} \mathrm{H}_{5}\right)_{2} \mathrm{C}=C\right), 91.6(\mathrm{C} \equiv C$ or $\left.\left(\mathrm{C}_{6} \mathrm{H}_{5}\right)_{2} \mathrm{C}=C\right), 103.4\left(\mathrm{C} \equiv C\right.$ or $\left.\left(\mathrm{C}_{6} \mathrm{H}_{5}\right)_{2} \mathrm{C}=C\right), 128.1\left(o-C_{6} \mathrm{H}_{5}\right), 128.6\left(p-C_{6} \mathrm{H}_{5}\right), 130.5(m-$ $\left.\mathrm{C}_{6} \mathrm{H}_{5}\right), 141.3\left(\left(\mathrm{C}_{6} \mathrm{H}_{5}\right)_{2} \mathrm{C}=\mathrm{C}\right), 153.5\left(i-\mathrm{C}_{6} \mathrm{H}_{5}\right)$. ASAP MS(+): $m / z 597.1[\mathrm{M}+\mathrm{H}]^{+}$. Analysis found: C 76.38, $\mathrm{H} 4.61 \%$; required for $\mathrm{C}_{38} \mathrm{H}_{28} \mathrm{Fe}_{2}$ : C 76.54, $\mathrm{H} 4.73 \%$.

\section{Preparation of $\mathrm{FcCH}=\mathrm{C}(\mathrm{C} \equiv \mathrm{CFc})_{2}(6 \mathrm{~b})$}

Ethynyl ferrocene (250 mg, $1.19 \mathrm{mmol}), \mathbf{1 b}(200 \mathrm{mg}, 541 \mu \mathrm{mol})$, [Pd(PPh 3$\left.)_{4}\right]$ (32 $\mathrm{mg}, 27.7 \mu \mathrm{mol})$ and $\mathrm{CuI}(5.00 \mathrm{mg}, 27.7 \mu \mathrm{mol})$ were dissolved in triethylamine $(20 \mathrm{ml})$. The reaction mixture was heated to reflux for $20 \mathrm{~h}$, cooled to ambient temperature and the solvent was removed in vacuo. The residue was purified by column chromatography (eluent: hexanes to hexanes/dichloromethane 150:50 $(\mathrm{v} / \mathrm{v}))$ ) concentration of the relevant fractions afforded $\mathbf{6 b}(231 \mathrm{mg}, 68 \%)$ as a bright red solid. Crystals suitable for X-ray diffraction were grown by slow evaporation from a dichloromethane solution. ${ }^{1} \mathrm{H}$ NMR $\left(\mathrm{CD}_{2} \mathrm{Cl}_{2}\right): \delta 4.25(5 \mathrm{H}, \mathrm{s}$, $\left.\mathrm{C}_{5} \mathrm{H}_{5}\right), 4.26\left(2 \mathrm{H}, \mathrm{m}, \mathrm{C}_{5} H_{4}\right), 4.27\left(5 \mathrm{H}, \mathrm{s}, \mathrm{C}_{5} \mathrm{H}_{5}\right), 4.30$ (2 H, m, $\left.\mathrm{C}_{5} \mathrm{H}_{4}\right), 4.33$ (5 H, s, $\left.\mathrm{C}_{5} \mathrm{H}_{5}\right)$, $4.45\left(2 \mathrm{H}, \mathrm{m}, \mathrm{C}_{5} \mathrm{H}_{4}\right), 4.49\left(2 \mathrm{H}, \mathrm{m}, \mathrm{C}_{5} \mathrm{H}_{4}\right), 4.59\left(2 \mathrm{H}, \mathrm{m}, \mathrm{C}_{5} \mathrm{H}_{4}\right), 4.93\left(2 \mathrm{H}, \mathrm{m}, \mathrm{C}_{5} \mathrm{H}_{4}\right)$, $6.87(1 \mathrm{H}, \mathrm{s}, \mathrm{CH}=\mathrm{C}) .{ }^{13} \mathrm{C}$ NMR $\left(\mathrm{CD}_{2} \mathrm{Cl}_{2}\right): \delta 65.7\left(\mathrm{C}-\mathrm{C} \equiv \mathrm{C}, \mathrm{C}_{5} \mathrm{H}_{4}\right), 65.8\left(\mathrm{C}-\mathrm{C} \equiv \mathrm{C}, \mathrm{C}_{5} \mathrm{H}_{4}\right)$, $69.3\left(C-\mathrm{H}, \mathrm{C}_{5} \mathrm{H}_{4}\right), 69.6\left(C-\mathrm{H}, \mathrm{C}_{5} \mathrm{H}_{4}\right), 69.9\left(C-\mathrm{H}, \mathrm{C}_{5} \mathrm{H}_{4}\right), 70.0\left(C_{5} \mathrm{H}_{5}\right), 70.3\left(C_{5} \mathrm{H}_{5}\right), 70.4$ $\left(C_{5} \mathrm{H}_{5}\right), 70.6\left(C-\mathrm{H}_{2} \mathrm{C}_{5} \mathrm{H}_{4}\right), 71.6\left(C-\mathrm{H}, \mathrm{C}_{5} \mathrm{H}_{4}\right), 71.7\left(C-\mathrm{H}, \mathrm{C}_{5} \mathrm{H}_{4}\right), 80.6\left(C-\mathrm{CH}=\mathrm{C}, \mathrm{C}_{5} \mathrm{H}_{4}\right)$, $84.8(C \equiv \mathrm{C}), 86.2(\mathrm{CH}=C), 86.4(C \equiv \mathrm{C}), 93.3(C \equiv \mathrm{C}), 100.6(C \equiv \mathrm{C}), 142.5(\mathrm{CH}=\mathrm{C})$. ASAP-MS(+): $m / z 629.0[\mathrm{M}+\mathrm{H}]^{+}$. Analysis found: C 68.82, H 4.50\% required for $\mathrm{C}_{36} \mathrm{H}_{28} \mathrm{Fe}_{3}: \mathrm{C} 68.84, \mathrm{H} 4.49 \%$.

Crystal data for $6 \boldsymbol{b}: \mathrm{C}_{36} \mathrm{H}_{28} \mathrm{Fe}_{3}, \mathrm{M}=628.13$, monoclinic, space group $C c, a=$

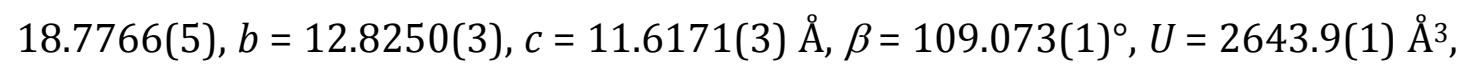
$F(000)=1288.0, Z=4, D_{\mathrm{c}}=1.578 \mathrm{mg} \mathrm{m}^{-3}, \mu=1.649 \mathrm{~mm}^{-1} .15594$ reflections were collected yielding 6689 unique data $\left(R_{\operatorname{merg}}=0.0319\right)$. Final $w R_{2}\left(F^{2}\right)=0.1101$ for all data (330 refined parameters), conventional $R_{1}(F)=0.0427$ for 5980 reflections with $I \geq 2 \sigma$, GOF $=1.065$, Flack $=0.41(2)$ 


\section{Preparation of $\mathrm{FcCH}=\mathrm{C}\left(\mathrm{C} \equiv \mathrm{CAuPPh}_{3}\right)_{2}$ (7)}

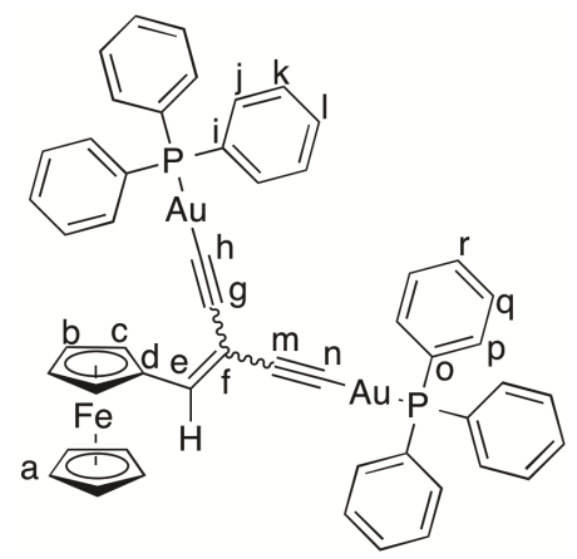

A solution of $\mathbf{2 b}(100 \mathrm{mg}, 0.247 \mathrm{mmol}$ as a $25 \mathrm{mg} / \mathrm{ml}$ solution in THF) $\{$ Vincent:2013fd $\}$ was treated with methanol $(15 \mathrm{ml})$ and $\mathrm{NaOH}(99 \mathrm{mg}, 2.47$ mmol) and the solution stirred for 30 minutes. After this time, [ $\left.\mathrm{AuCl}\left(\mathrm{PPh}_{3}\right)\right]$ (247 $\mathrm{mg}, 0.499 \mathrm{mmol}$ ) was added, and the reaction allowed to stir for a further 3 hours. The reaction mixture was filtered, and the precipitate washed with methanol $(3 \times$ $10 \mathrm{ml})$ and hexane $(3 \times 10 \mathrm{ml})$ and dried in air to give the title compound. Yield $206 \mathrm{mg}, 71$ \%. ${ }^{1} \mathrm{H}$ NMR $\left(\mathrm{CD}_{2} \mathrm{Cl}_{2}\right): \delta 4.16\left(5 \mathrm{H}, \mathrm{s}, \mathrm{H}_{a}\right), 4.26\left(2 \mathrm{H}, \mathrm{vt}, J=2 \mathrm{~Hz}, \mathrm{H}_{c}\right), 4.96$ $\left(2 \mathrm{H}, \mathrm{vt}, J=2 \mathrm{~Hz}, \mathrm{H}_{b}\right), 6.56\left(1 \mathrm{H}, \mathrm{s}, \mathrm{H}_{e}\right), 7.49\left(12 \mathrm{H}, \mathrm{m}, \mathrm{H}_{j}\right.$ and $\left.\mathrm{H}_{p}\right), 7.54\left(6 \mathrm{H}, \mathrm{m}, \mathrm{H}_{l}\right.$ and r), $7.55-7.62\left(12 \mathrm{H}, \mathrm{m}, \mathrm{H}_{k}\right.$ and $\left.\mathrm{H}_{q}\right)$. ${ }^{31} \mathrm{P}$ NMR $\left(\mathrm{CD}_{2} \mathrm{Cl}_{2}\right): \delta 42.20(\mathrm{~s}), 42.41(\mathrm{~s}) .{ }^{13} \mathrm{C}$ NMR ( $\left.\mathrm{CD}_{2} \mathrm{Cl}_{2}\right): \delta 69.65\left(\mathrm{C}_{c}, \mathrm{~s}\right), 69.78\left(\mathrm{C}_{b}, \mathrm{~s}\right), 69.84\left(\mathrm{C}_{a}, \mathrm{~s}\right), 69.99\left(\mathrm{C}_{m}, \mathrm{~s}\right), 70.02\left(\mathrm{C}_{g}, \mathrm{~s}\right)$, $82.37\left(\mathrm{C}_{d}, \mathrm{~s}\right), 102.91\left(\mathrm{C}_{n}, \mathrm{~d}, J=27 \mathrm{~Hz}\right), 103.39\left(\mathrm{C}_{f}, \mathrm{~s}\right), 105.53\left(\mathrm{C}_{h}, \mathrm{~d}, J=27 \mathrm{~Hz}\right), 129.64$ ( $\mathrm{C}_{p}, \mathrm{~d}, J=5 \mathrm{~Hz}$ ), 129.7 ( $\mathrm{C}_{j}, \mathrm{~d}, J=5 \mathrm{~Hz}$ ), 130.44 ( $\left.\mathrm{C}_{o}, \mathrm{~s}\right), 139.22$ ( $\left.\mathrm{C}_{e}, \mathrm{~s}\right), 130.75\left(\mathrm{C}_{i}, \mathrm{~s}\right)$, $132.04\left(\mathrm{C}_{r}, \mathrm{~s}\right), 132.06\left(\mathrm{C}_{l}, \mathrm{~s}\right), 134.65\left(\mathrm{C}_{q}, \mathrm{C}_{d}, J=5 \mathrm{~Hz}\right), 134.90\left(\mathrm{C}_{k}, \mathrm{C}_{d}, J=5 \mathrm{~Hz}\right)$. MALDI-MS(+): $m / z 1176.1[\mathrm{M}]^{+}$. IR $\left(\mathrm{CH}_{2} \mathrm{Cl}_{2}\right) v(\mathrm{C} \equiv \mathrm{CAu}) 2102 \mathrm{~cm}^{-1}, v(\mathrm{C}=\mathrm{C}) 1481$ $\mathrm{cm}^{-1}$. Analysis found C 52.93, H 3.34\% required C 53.06, H 3.34\%. 
X-ray Crystallography

The X-ray single crystal data have been collected using $\lambda \mathrm{MoK} \alpha$ radiation $(\lambda$ $=0.71073 \AA$ ) on a Bruker SMART 6000 (fine-focus sealed tube, graphite monochromator, Monocap optics) (compounds 5a and 6b) and Agilent XCalibur (Sapphire-3 CCD detector, fine-focus sealed tube, graphite monochromator) (4a) diffractometers equipped with a Cryostream (Oxford Cryosystems) open-flow nitrogen cryostats at the temperature 120.0(2) K. All structures were solved by direct method and refined by full-matrix least squares on $F^{2}$ for all data using Olex2 [67] and SHELXTL [68] software. All non-disordered non-hydrogen atoms were refined anisotropically the hydrogen atoms were placed in the calculated positions and refined in riding mode. Disordered atoms in structure $6 \mathbf{b}$ were refined isotropically with fixed $\mathrm{SOF}=0.5$. Crystallographic data for the structure have been deposited with the Cambridge Crystallographic Data Centre as supplementary publication CCDC-1518244-1518246.

\section{Acknowledgments}

We gratefully acknowledge funding from the EPSRC (EP/H005595/1) and ARC (DP 140100855). PJL holds an ARC Future Fellowship (FT 120100073). FH thanks EPSRC for funding (EP/K00753X) and the University of Reading for the support of the Reading Spectroelectrochemistry laboratory (Project D14-015).

\section{References}

\{papers2_bibliography\} 